\title{
Consequences of inadequate food energy and negative energy balance in humans
}

\author{
AV Kurpad*, S Muthayya and M Vaz \\ Division of Nutrition, Institute of Population Health and Clinical Research, St. John's National Academy of Health \\ Sciences, Bangalore 560 034, India
}

\begin{abstract}
Energy deficiency is probably best measured in adults by the body mass index (BMI). Acute energy deficiency (AED) is associated with body weight loss, along with changes in body composition, as well as a reduced BMR and physical activity. Chronic energy deficiency (CED) is an inadequacy in food to which individuals adapt, at some cost. Individuals with this have never 'lost' weight: they have simply grown less. They adapt to the decreased food energy by reductions in their total energy expenditure (TEE), linked mainly to a lower body size, and to their physical activity. It seems unlikely that enhanced metabolic efficiency contributes substantially to energy saving in CED. Supplementation of energy deficient individuals is accompanied by significant fat deposition; this may have deleterious consequences.

Women in many developing countries achieve a successful outcome to pregnancy in spite of being chronically undernourished. Reductions in basal metabolism and behavioural changes in the form of diminished physical activity could meet most of the extra energy needed for pregnancy. Milk energy output is maintained within the expected range in undernourished lactating mothers. Energy deficiency in children is best measured by height-for-age for stunting, and weight-for-height for wasting. Deficits in behavioural and functional parameters in children exist with undernutrition, and can be reduced by early nutritional supplementation along with the appropriate environment.
\end{abstract}

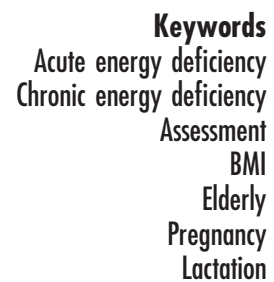

\section{Introduction}

Energy deficiency can be acute or chronic. Acute energy deficiency (AED) is by nature episodic, and characterised by a state of negative energy balance, wherein the energy expenditure is greater than energy intake. Under these conditions, there is a progressive loss of body weight, along with changes in the pattern of energy expenditure, in an attempt by the body to come into a new, but lower plane of energy equilibrium. If the energy deficiency persists, further weight loss occurs along with deterioration in health ultimately leading to death. It is not merely the temporal effect of AED that determines the outcome; the intensity or magnitude of the energy deficit is also a factor. On the other hand, chronic energy deficiency (CED) is a 'steady state', due to inadequate food energy over a lifetime. Individuals with CED are, a priori, in energy balance, although their anthropometric parameters, as described later, may be less than desirable. By definition, these individuals have never 'lost' weight, but, having been exposed to a lower than normal energy intake during their lives, have attained an energy equilibrium with a lower body weight, a lower body energy store, and reduced physical activity. However, in spite of these drawbacks, these individuals continue to live relatively normal and economically productive lives; the terms normal and productive must be viewed in the proper perspective of this condition, as they do not refer to the optimal. There is good evidence to show that persons with CED are less productive, and that the CED state is associated with higher morbidity and mortality and these issues will be discussed later in this review. In addition, the steady state referred to above must be appreciated as a theoretical one, subject to periodic fluctuations of physiology and environment, such as the menstrual cycle $^{1}$ and seasons ${ }^{2}$. From the population health viewpoint, it is CED that is important to prevent and address.

While these two definitions of energy deficiency seem mutually exclusive, the two conditions of chronic and AED may co-exist in the form of episodic acute-on-chronic conditions. Further, there may be groups whose status (in terms of the definitions above) is difficult to define, such as in refugees, where a period of AED may result in a new equilibrium state of deficiency, albeit of a chronic nature. An analogous situation exists for children, where more chronic, marginal energy and nutrient deficiency leads to 
stunting, while acute energy and nutrient deficiency leads to wasting. However, in this review, the terms 'acute' and 'chronic' energy deficiency have not specifically been used with reference to children, because the historical terms relating to acute and chronic deficiency (relations between weight, height and age, as well as wasting or stunting) in children seemed adequate to describe the effects of energy deficiency, in the absence of data relating the effects of other indices, such as a low body mass index (BMI), on morbidity and mortality in this group. More importantly, marginal energy-nutrient deficiency in this group leads to deficits other than growth, such as in behavioural and cognitive outcomes.

\section{Assessment of energy deficiency in adults}

\section{Body Mass Index}

While definitions of CED have been based on considerations of energy intake and expenditure, one simple way to measure it would be based on anthropometry ${ }^{3}$. The demonstration of a low height (i.e. stunting) is indicative of childhood energy undernutrition ${ }^{4}$ but it does not reflect current nutritional status. The latter is best measured by a surrogate of body energy stores, or, the Body mass index (BMI) computed as the weight $(\mathrm{kg}) /$ height $(\mathrm{m})^{2}$. This index shows a consistently high correlation with weight, and is relatively independent of the height ${ }^{5}$. The problem then, is one of defining cut-off points for CED. The usual standard that has been used is the BMI of male soldiers and healthy men and women (UK) with a value of two standard deviations below the mean, as the cut-off point. This gives a value of $18.5 \mathrm{~kg} \mathrm{~m}^{-2}$, which is used for both men and women. It is important to realise that this is still an arbitrary cut-off; ideally, this cut-off value to determine CED should be based on epidemiological data showing the relationship between low BMI and the risk of morbidity of populations. Data is available showing a threefold higher risk of mortality in men with a BMI $<16.0 \mathrm{~kg} \mathrm{~m}^{-2}$ when compared with men with a BMI $>18.5 \mathrm{~kg} \mathrm{~m}^{-26}$. In addition there is also a progressive reduction in the mean birth weight of babies born to mothers with low $\mathrm{BMI}^{7}$. Since a BMI of 18.5 and above is compatible with health in both men and women, a cut-off of $18.5 \mathrm{~kg} \mathrm{~m}^{-2}$ has been adopted for both sexes ${ }^{8}$. Three grades of CED are now defined, based on progressively diminishing BMI, such that BMI between 17.0 and $18.5 \mathrm{~kg} \mathrm{~m}^{-2}$ is considered Grade I CED, BMI between 16.0 and $16.9 \mathrm{~kg} \mathrm{~m}^{-2}$ is considered Grade II CED, and BMI $<16.0 \mathrm{~kg} \mathrm{~m}^{-2}$ is considered Grade III or severe CED. It is clear that healthy, thin and tall adults with a low BMI, but a high energy turnover would be misclassified as CED with this system. This concern led to the addition of a measure of energy turnover to the original classification, such that the demonstration of a low energy turnover was necessary before classifying individuals with a low BMI as having CED. The cut-off for this low energy turnover was based on a physical activity level (PAL, ratio of total energy expenditure (TEE) to basal metabolic rate) of 1.4 . However, there are two problems with this approach ${ }^{2}$. Firstly, an analysis of the activities of women from less developed countries showed that they were capable of sustaining economically productive activities for up to $4.5 \mathrm{~h} \mathrm{day}^{-1}$, without exceeding the PAL cut-off of 1.4. This was because a lot of their activities during the day were performed sitting down, with attendant low energy costs of activity. Secondly, the measurement of PAL is difficult and subject to a lot of variability. The classification of the populations studied, into different grades of CED based on BMI and PAL, produced a non-Gaussian distribution, unlike BMI alone, which produced a more classical distribution ${ }^{2}$. These observations have led to the recommendation that $\mathrm{BMI}$ alone be used to diagnose CED.

From another perspective, the measurement of a low PAL may not be necessarily present in individuals with CED. In order to sustain economically productive (and sometimes, seasonally increased) activity in the face of a constant low energy intake, individuals with CED will have to continue their physical activity; the cost of this maintained activity will be a non-steady state of body weight loss until the individuals come into equilibrium with their energy intake once again ${ }^{3}$. An additional measurement that may be of some use in assisting the classification of subjects as chronically energy deficient, is the measurement of their socio-economic status, since Ferro-Luzzi et $a l^{2}$ found that the proportion of CED in a population increased as poverty increased. Reddy ${ }^{9}$ has also shown that socio-economic and behavioural variables showed significant effects on age adjusted BMI. This approach is particularly useful when assessing subjects who are tall and thin, with a high-energy turnover, as may occur in developing countries.

The shape of the human body can also determine the BMI, particularly the ratio of leg length to trunk length, which is also called the Cormic Index ${ }^{10}$. There is considerable variation in this index both between and within populations ${ }^{11,12}$, and therefore, it has been suggested that in inter-population comparisons, as well as in BMI measurements in individuals, a correction to the $\mathrm{BMI}$ be made based on the Cormic Index ${ }^{12,10}$.

\section{Body Mass Index and energy stores}

If body energy stores were the prime consideration, then a more specific index of body fat would be required, since it has been shown that in normal people at any given range of BMI and age, there is a wide range of body fat expressed as a percentage of weight ${ }^{8,13}$. The BMI is highly correlated with the fat mass of the body ${ }^{13}$ although this relationship is not as good among the very young and the elderly. In general, there is a loss of fat free mass (FFM) and a gain of fat as people age $\mathrm{e}^{14}$ and the fat composition of the body varies in different populations ${ }^{8,15-17}$. With age and gender 
specific equations however, the prediction of body fat percent is fairly accurate ${ }^{18}$. This holds true for people from developing countries as well ${ }^{15}$.

\section{Adaptations to, and consequences of, a negative energy balance}

\section{Acute energy deficiency}

Effects on body composition

The effects of AED have been studied in normal and obese individuals, in relation to several parameters such as the body composition, and components of energy expenditure. This review will focus on studies assessing AED in normal weight subjects only. The weight loss on starvation is initially rapid (up to $5 \mathrm{~kg}$ over a few days), due to the depletion of glycogen reserves, the utilisation of body protein and the water loss that accompanies this ${ }^{19}$. The loss of body tissue that accompanies negative energy balance is composed of primarily fat, although varying amounts of lean tissue are lost as well. During the 6 month semistarvation study of Keys et al. ${ }^{20}$, in which normal subjects were fed at an average energy intake of $6.6 \mathrm{MJ} \mathrm{day}^{-1}$, the lean tissue loss was $57 \%$ of the total weight loss, and overall, the subjects had already reached the nadir of their body fat halfway through the study. These subjects were initially physically active, and the energy deficit in such individuals was met in part, by mobilisation of their fat stores. Although physical activity would have been expected to maintain muscle mass in such a situation; it is clear that lean tissue is also catabolised to provide energy in the face of large energy deficits.

While this type of energy restriction is severe, a recent 2 year study ${ }^{2}$ on individuals living in an enclosed environment Biosphere 2, and subjected to a milder degree of energy restriction resulted in a decline of $\sim 15 \%$ of body weight at the end of the 2 year period. Longitudinal data is not available for the subjects in these experiments, but their low body fat $(\sim 10 \%)$ at the end of the study indicated that a substantial part of their body weight loss was due to fat loss. In another study on active young men ${ }^{22}$ given an energy deficit of about $5 \mathrm{MJ}$ $(1200 \mathrm{kcal}) / \mathrm{d}$, it was found that most subjects reached a body fat content of about 4-6\%, after a period of 8 weeks, and the proportion of fat loss to total weight loss was about 0.6. The proportions of fat loss was dependent on the initial adiposity ${ }^{23}$, and although the subjects reached their nadir fat content before the end of 8 weeks, the lean tissue loss did not increase beyond about $7 \%$ of the initial FFM, due to possible metabolic efficiencies that decreased energy demand, and hence weight loss rates. The composition of weight loss is dependent on different conditions under which the negative energy balance is imposed: in healthy, normal young men, the weight loss is composed of fat and FFM, while in obese individuals it may be primarily fat mass ${ }^{24}$.

\section{Effects on basal metabolic rate}

Accompanying the changes in body composition during acute negative energy balance, are adaptive changes in energy expenditure. Reductions in the basal metabolic rate (BMR) are partly mediated through weight loss itself, in which metabolically demanding tissues of the body are reduced in size. However, it is clear that the metabolic activity of these is reduced as well. In the semi-starvation study referred to before ${ }^{20}$, the subjects' BMR decreased by about $27 \%$ when expressed per kilogram of FFM, compared with an almost 40\% decline in whole body BMR from the initial value. The decline in BMR per kg FFM was most rapid in the first 2 weeks, indicating that the reduced metabolic activity of the fat free tissue occurred quickly in response to energy deficiency. In a re-analysis of the data from the Minnesota experiment, it appeared that the reduction in BMR after semi-starvation was correlated with the loss in fat mass (but not loss of FFM), and this has been hypothesised to be due to feedback signals from fat stores which adaptively diminish the thermogenesis (and therefore the BMR) in normal weight individuals $^{25}$. A similar reduction in BMR or sedentary energy expenditure per $\mathrm{kg}$ active tissue has also been observed in other studies, with different types of semistarvation based on decreasing the intake of single nutrients or all nutrients, or with complete starvation ${ }^{26-}$ 31. In the Biosphere 2 experiment ${ }^{21}$, the sleeping metabolic rate (SMR) was measured 1 week after the subjects had exited the Biosphere (after 2 years) and was found to be significantly lower in the subjects when compared to controls, but just below significance after adjustments for age, gender, fat and FFM. However, these subjects were studied some 3-8 days after exiting the Biosphere, and in this intervening period were allowed an ad libitum diet, which could have had an effect on the SMR.

On the other hand, there are also findings of an increased BMR per kg body weight in a number of clinical studies arising from energy deficiency, and it is possible that these conflicting findings are due to several factors, such as whether the patient was in a state of recovery or not, or due to methodological errors during the conduct of BMR measurement ${ }^{32}$. The ingestion of food in recovering malnourished children or adults can also increase the BMR. For instance, the BMR per kg body weight was increased in a study which re-fed adult men who had earlier been subjected to a negative energy balance ${ }^{26}$. Similarly, a 3-month re-feeding regimen in chronically energy deficient men also demonstrated an increase in BMR per kg body weight ${ }^{33}$.

The conflicting findings of change in BMR per kilogram of body weight or FFM can partly be explained by examining the composition of the fat free tissue loss, and the organ contribution to metabolic rate ${ }^{32}$. Table 1 shows the relative loss of different tissues in atrophic infants ${ }^{32}$, where the brain, viscera and skeleton are relatively 
Table 1 Body composition of atrophic infants

\begin{tabular}{lc}
\hline & Percentage of normal \\
\hline Whole body & 52 \\
Brain & 90 \\
Kidneys & 80 \\
Heart & 60 \\
Fat & 5 \\
Skeleton & 85 \\
Muscle & 30 \\
\hline
\end{tabular}

Source: Data from $\mathrm{Elia}^{32}$.

preserved when compared to muscle and fat. Indeed, the rate of both muscle and adipose tissue are higher than other tissues during acute under-nutrition ${ }^{29,34}$. Since these tissues have relatively lower metabolic rates than visceral organs $^{29}$ and since the organ mass has been shown to be inversely related to the $\mathrm{FFM}^{35}$, it is possible that the BMR per kg FFM, would depend largely on these factors. It is also possible that there may be alterations in the metabolic rates of individual organs, contributing to an increase or decrease of the BMR per kg FFM. Therefore, the change in BMR per kg FFM is dependent on a balance between the greater loss of relatively inactive tissue such as fat and muscle and a potential reduction in the metabolic rate of the fat free tissues. However, when the negative energy balance is complicated by disease, the metabolic rate of visceral tissues is likely to increase.

\section{Factors underlying the decrease in BMR}

The factors underlying the decrease in the activity of the FFM have been reviewed by Shetty ${ }^{36,37}$, in both acute and chronic undernutrition, and include reduced activity of the sympathetic nervous system, altered peripheral thyroid metabolism and lowered insulin secretion, along with substrate utilisation designed to maintain glucose production and maximise fat usage. Leptin (the $o b$ gene product), which is expressed in adipose tissue and secreted into the circulation, acts at the hypothalamic level as a lipostatic mechanism through modulation of satiety and the activity of the sympathetic nervous system $^{38,39}$. Another mechanism by which leptin may act to increase energy expenditure is through changes in the expression of uncoupling proteins ${ }^{40}$. Significant decreases in serum leptin concentrations, which were highly correlated with weight and body fat, have been shown in anorexia nervosa ${ }^{41}$, and a recent study demonstrated that plasma leptin levels were positively correlated with the BMR adjusted for FFM in anorexia nervosa patients ${ }^{42}$. This suggests that leptin is important in undernourished, low fat mass states, as a potential modulator of the energy sparing response to energy deficiency. An additional modulator of the response to underfeeding is the genetic makeup of the individual. Therefore, the effects of changes in environmental conditions (in this case, negative energy balance) would be similar in a group of individuals if their genetic makeup was unimportant; however, if dissimilar effects were observed for exactly similar environmental conditions, then there must be a gene-environment interaction ${ }^{43}$. There are of course other variables that must be considered when analysing these experiments, such as the condition (for example, energy store) of the subjects before the start of the environmental change. In one study on monozygotic twin pairs, Bouchard et al. ${ }^{44}$ measured the body weight and compositional change after 93 days of negative energy balance induced by increased exercise with constant dietary intake. The within-pair variation was much less than the between-pair variation for loss of weight, body fat, visceral fat and respiratory exchange ratio during exercise (see Fig. 1), showing that subjects with the same genotype were more alike in responses than subjects with different genotypes. On the other hand, there was also no twin resemblance in the RMR adjusted for FFM. These observations support the existence of gene-energy balance interactions in determining the response of individuals to negative energy balance.

\section{Effects on thermogenesis}

Changes in thermogenesis could also account, in part, for decreased TEE in response to total or semi-starvation. The changes in cold induced thermogenesis are not as consistent or dramatic as the fall in BMR in acute negative energy deficiency. Over short durations of complete starvation ( 48 hours), there is a reduction of core temperature in response to cooling, but this is due to an inappropriately small vasoconstrictor response, rather than a thermogenic defect ${ }^{45}$. The thermogenic response to acute undernutrition over a week has been studied in

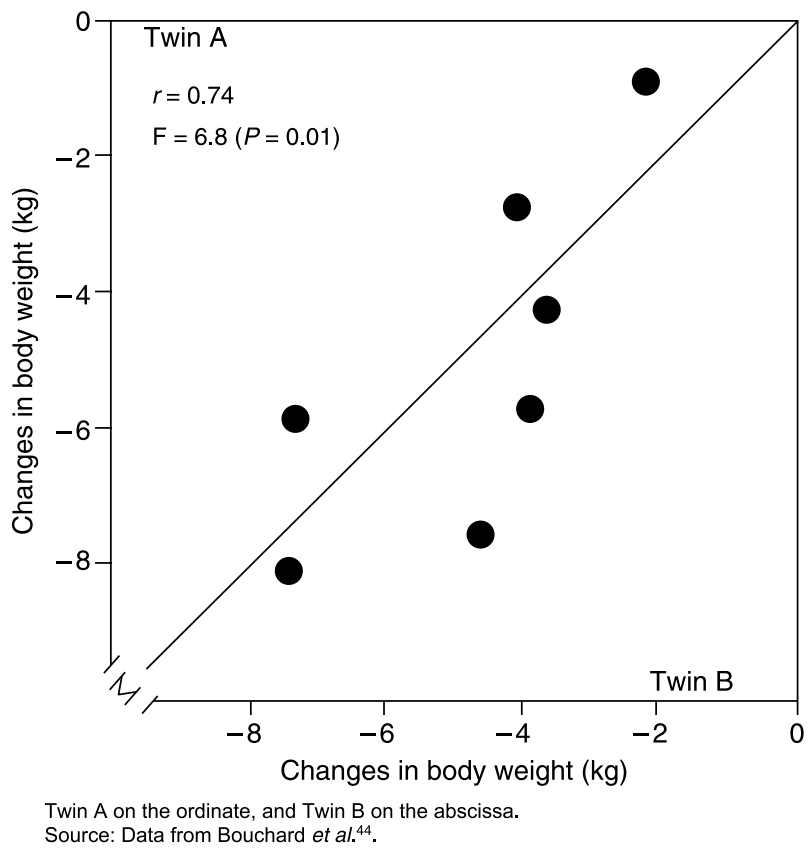

Fig. 1 Changes in body weight with negative energy balance in seven pairs of twins 
young women, who lost $2 \mathrm{~kg}$ of body weight, and showed no reduction in response to cooling, however, in the same model of underfeeding, the thermic effect of a glucose and insulin infusion was abolished, although the glucose disposal rates remained essentially similar ${ }^{46-48}$. In a more chronic model of undernutrition using elderly undernourished women admitted into hospital with fractured femurs, it was found that the thermogenic response to a cold stimulus was reduced ${ }^{49}$ when compared to similar but normally nourished patients, although the undernourished women were slightly, but significantly older than the control group. The reduced thermogenic response (if a decline in BMR is considered to include a decreased thermogenesis) in AED may also be part of a feedback loop, which regulates the fat deposition on acute re-feeding ${ }^{25,50}$, although other underfeeding studies have not observed a similar effect on either the RMR or on subsequent weight gain after an intervening period of 4 years $^{51}$. This interesting possibility, of the long-term effects of weight loss on subsequent weight (and specifically fat) regain, needs more study.

\section{Effects on physical activity}

Changes in physical activity are also effective in reducing TEE. It should be emphasised that the changes in physical activity may not be a matter of a self-selected strategy or choice, for individuals subjected to energy deficiency, but a consequence of the process, and all descriptions of a reduction in physical activity in this review are subject to this caveat. In the Minnesota study ${ }^{20}$, the physical activity of the subjects was noted to decline with semi-starvation; if it is assumed that the subjects were in a near steady state of energy balance at the beginning and end of the study (since their body weight declined at a very slow rate at the end of the 6-month study), it is reasonable to calculate their PAL as the ratio of BMR to energy intake. Thus, the subjects, who were on activity schedules, showed a decline of PAL from about 2.1 to about 1.6. The decline in BMR would have only accounted for about $34 \%$ of the adaptive decrease in energy expenditure while the decline in physical activity plus thermogenesis would account for the major component of the adaptive energy saving response. In the Biosphere experiment ${ }^{21}$, subjects demonstrated a PAL of 1.7 near the end of their 2-year confinement, and this suggests that they were able to be active despite their lower than normal intake, and the subjects appeared to be in energy balance at the time. Although this appears counter-intuitive, it must be remembered that these individuals were subjected to energy intakes of about $7.5 \mathrm{MJday}^{-1}$ during the first 6 months of their confinement, during which their body weights declined by $15 \%$. In the next 18 months, food availability stabilised at a lower than normal level, but the subjects were able to remain in equilibrium, maintaining relatively stable body weight with this lowered intake, by reductions in their energy expenditure but not their physical activity. They, however, did demonstrate decreased TEE (by about 6\% when compared to controls), even after adjusting for age, gender, fat and FFM; this suggests that there were spontaneous reductions in physical activity of a non-volitional nature, since their volitional activities continued. This situation appears to be analogous with what is found in chronically energy deficient subjects.

In addition to the foregoing, it is also possible that there could be an efficiency associated with physical activity, however, in experiments where the energy cost of specific activities has been measured, there was found to be little if no change in metabolic efficiency. This efficiency is the ratio between the work done, and the energy expended in doing the work. In the Minnesota experiment, treadmill data demonstrated a significantly higher gross efficiency after 6 months of starvation, however there was no difference in net efficiency. Higher gross efficiency has also been found in Jamaican subjects with a low energy intake, doing the step test, when compared to controls ${ }^{52}$. Physical strength can also decline with AED, and in the Minnesota experiment $^{20}$, it was found that grip strength declined by about $30 \%$ by the end of the 6-month semi-starvation period. Similarly, after a 20\% energy restriction study for 10 weeks on normal middle aged men, it was observed that the energy restricted men demonstrated a shorter exercise time and lower maximal power output when tested to exhaustion with bicycle ergometry ${ }^{53}$.

From the behavioural viewpoint, the imposition of an AED causes apathy with a marked reduction in spontaneous activity, and a lack of motivation to undertake activities ${ }^{20}$. A decrease in food intake also results in a change in selection of discretionary activity patterns, such that lower activity discretionary patterns are selected, although obligatory activities are not affected ${ }^{54}$. Keeping in mind the caveat of 'choice' vs. 'consequence', these behavioural changes maximise the chances of survival under conditions of AED, and this was also demonstrated in the Biosphere experiment ${ }^{21}$, where 'spontaneous' physical activity of the subjects was significantly less than that of controls.

\section{Summary}

Overall therefore, it appears that acute short-term or longer-term energy deficiency, whether experimental or associated with pathology, is associated with body weight loss, along with changes in body composition, as well as a reduced BMR and physical activity. An additional adaptive finding is the decline in metabolic activity of the FFM in uncomplicated energy deficiency. The weight loss and lower BMR may indeed be the sine qua non of AED especially in the context of comparisons with CED. However, when the negative energy balance is complicated by associated pathology, the changes in body weight loss and composition may be more dramatic, and the metabolic activity of tissues will actually increase. 


\section{Chronic energy deficiency}

CED is defined as a weight-stable energy balance state, in the presence of lower than normal energy intakes. This state is achieved by the presence of low body weight and fat stores, but the individual's health is normal and body physiological function is not compromised to the extent that the individual is unable to lead an economically productive life ${ }^{3}$.

\section{Effects on body composition}

Anthropometrically, the consequence of an inadequate energy intake during the childhood and adolescence of an individual is a reduced body size, and a low BMI. In individuals with CED, there is also stunting due to the presence of low energy intakes and concomitant repeated infections in childhood and adolescence ${ }^{55}$. A crosssectional study on the measurement of the fat and FFM by hydrodensitometry, in men and women recruited from the lowest socio-economic class in urban India, with BMIs ranging from normal to Grade II CED showed that the mean percent body fat was different ( 15.5 vs. $9.8 \%$ in men, normal vs. grade II CED). For women, a higher body fat was noted, but the percent body fat in normal women was $24.8 \%$ compared to $15.4 \%$ in Grade II CED. The heights of the subjects were similar, with a pattern of lower weights as BMI decreased. About 60\% of the difference in body weight could be attributed to a difference in FFM in men, when comparing normal subjects to group I and II CED, however, in women, this proportion was less at between $40 \%$ and $50 \%{ }^{56}$.

This is similar to the composition of tissue lost after 24 weeks in the semi-starvation study of Keys et al. ${ }^{20}$ in normal, uninfected, active individuals, although it must be remembered firstly, that the rate of fat loss was not constant throughout this period, and secondly, that these situations are not strictly comparable, since, in CED, there is no tissue loss, as the subjects have never earlier had a higher body weight. In a study conducted 10 years earlier in a rural Indian population, Mc Neill et $a .^{57}$ demonstrated similar findings, in comparisons between low BMI $\left(16.6 \mathrm{~kg} \mathrm{~m}^{-2}\right)$ and normal BMI $\left(20.8 \mathrm{~kg} \mathrm{~m}^{-2}\right)$ individuals, in whom about $40 \%$ of the weight difference could be ascribed to fat. The composition of the weight difference was also similar to a study in low and normal BMI $\left(17.2\right.$ and $23.2 \mathrm{~kg} \mathrm{~m}^{-2}$, respectively) Gambian men, where the difference in FFM contributed $65 \%$ of the difference in body weight. The composition of the FFM may also differ from normal subjects in CED. Studies comparing subjects with CED and normally nourished subjects (BMI $>20 \mathrm{~kg} \mathrm{~m}^{-2}$ ) suggested, by indirect means, that the muscle to viscera ratio was decreased in $\mathrm{CED}^{58,59}$. Similar findings were found in studies on mild and severe malnutrition ${ }^{60}$, where the muscle cell to visceral cell ratio was lower in severe undernutrition (BMI <18.5), when compared to mild undernutrition.

\section{Effects on BMR}

The interest in the BMR of individuals with CED arose following the Food and Agriculture Organization/ World Health Organization/United Nations University (FAO/WHO/UNU) Expert Consultation report on Energy and Protein requirements ${ }^{61}$, which adopted the BMR as the basis of expressing energy requirements, therefore fuelling a search for metabolic efficiency and adaptation to lower energy intakes in these subjects. This committee also mentioned the need to clarify the extent to which the body can adapt to different levels of energy intake by change in the BMR. Besides the implications of precision of BMR estimates and their long-term stability, the important issue was the possibility that metabolic efficiency in energy utilisation at the cellular level would be a corollary to long-standing energy deficiency. Thus, one of the ways an individual with CED would adapt to their lower than normal energy intake, is by a reduction in their BMR. The smaller BMR occurs naturally as a result of a reduction in body size, however, it is important to note that in such individuals, who have never lost weight in the past, the BMR expressed per kg body weight or FFM, may not show similar effects as in individuals with AED. Indeed, although the total BMR is lower in these individuals, in a number of recent studies, the BMR per $\mathrm{kg}$ body weight was similar to, or higher, than control subjects ${ }^{57,58,62-65}$. In these studies, in which the subjects had BMIs that were comparable to the acute Minnesota study, the BMR when expressed per kilogram body weight was higher than normal, by up to $17 \%$. This applies to measurements of TEE as well ${ }^{65}$.

A possible reason for the higher BMR per kg body weight or FFM, is the change in the composition of the FFM, such that there is less tissue that is relatively metabolically inactive (muscle and fat) and proportionately more tissue that is relatively metabolically active (viscera) in individuals with CED when compared to normal individuals ${ }^{32,58,59}$. The linear relationship between the BMR and body weight (or FFM) has a positive intercept across a range of body weights ${ }^{66}$, it is clear that individuals with a smaller size will have a higher BMR per kg body weight or FFM. This can be addressed statistically by looking at the difference in BMR between different groups by an analysis of covariance, after which no differences in BMR were observed in most studies between individuals with CED and their normal controls ${ }^{56,58,65}$, except for one in which the difference persisted $^{67}$. In another comparison between Asian, Caucasian and African women, it was found that for the same FFM, there was no difference in the $\mathrm{BMR}^{68}$. Therefore, it is unlikely that there is any significant adaptation in the BMR (in terms of a lower BMR/kg FFM) as an energy saving mechanism in response to apparently lower than normal food intakes. This statement should be viewed in the light of the undoubted fall in the metabolic activity of lean tissue in acute semi-starvation. Thus, in situations of acute-onCED, as has been observed with seasonality of food 
availability $^{56}$, there may be evidence of adaptation in BMR in CED. This may also serve to explain the discrepant findings of a lower BMR adjusted for $\mathrm{FFM}^{67}$, or a lower BMR per $\mathrm{kg} \mathrm{FFM}^{69}$, in some studies in subjects with CED.

It is also known that the measured BMR of South Asians, and Africans ${ }^{65}$ is lower than their predicted $\mathrm{BMR}^{61}$ by some $10 \%$. This has been observed by Schofield ${ }^{70}$, by Henry and Rees ${ }^{71}$ in tropical populations, and in some ${ }^{65}$, but not all studies in Gambian men ${ }^{72}$. Although this was attributed to an effect of ethnicity on BMR, it is simply more likely that the prediction of BMR from linear equations using body weight may be erroneous since the slope of the relationship between BMR and weight is not likely to be the same at all ranges of body weights. In addition, the FAO/WHO/UNU equations relied upon a large number of Italian military subjects, whose BMR was higher than other Caucasian groups ${ }^{73}$; therefore, the prediction equations generated from this data set would overestimate the BMR, particularly at lower body weights. Figure 2 shows the mean group percentage difference between predicted and measured BMR plotted against the mean BMI in a variety of tropical populations, for men and women. It is interesting to note that in general, there is a preponderance of negative values (prediction greater than measured), and while the BMR of men is overestimated, the BMR of women is underestimated.

\section{Effects on thermogenesis}

There have been very few studies of thermogenesis and the sympathetic nervous system in CED. While subjects with AED show an abolition of the thermic response to glucose, as well as altered thermoregulation in response to cold $^{45,48}$, subjects with CED show a tendency to a

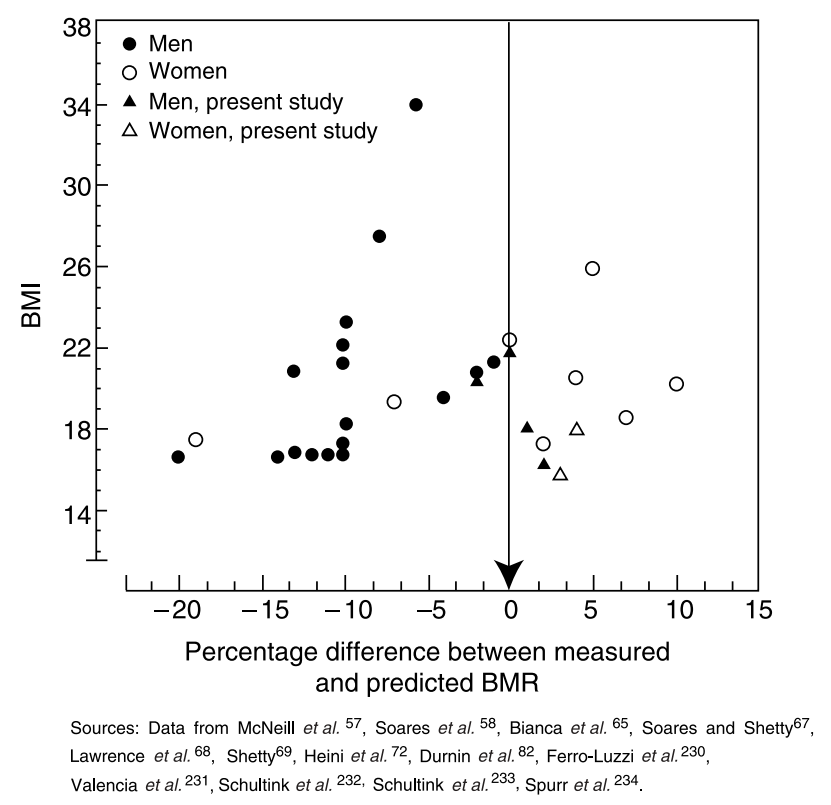

Fig. 2 Plot of percentage difference of mean measured and mean predicted basal metabolic rates (BMRs) of adult tropical populations against mean group BMI diminished noradrenaline stimulated thermogenesis ${ }^{63,64}$, although the difference in thermogenic response between the CED and control subjects was very small. It has been speculated that there is a reduced sympathetic nervous system drive in individuals with CED, and while the reduced thermogenesis is an energy saving mechanism, it would potentially be detrimental during exposure to cold $^{74}$. However, young male subjects with CED showed greater peripheral vasoconstrictive and thermogenic responses when they were exposed to mild cold, in comparison to well-nourished subjects ${ }^{75}$. The enhanced peripheral vasoconstrictive responses were similar to those observed in studies exploring the insulative properties of subcutaneous fat in lean and obese individuals ${ }^{76,77}$, but contrary to the lack of a vasoconstrictive response in an elderly group of women with a relatively longer term $\mathrm{AED}^{49}$. This suggests that, in young individuals with CED, thermoregulatory responses are well preserved and that the need for thermoregulation is greater than the need for energy conservation. However, these thermoregulatory studies were carried out under mild cold conditions, and it is not known whether subjects with CED can continue to show effective thermoregulation when exposed to severe cold. In studies on the thermic effect of a meal (TEM) in CED subjects, an increased total TEM response was seen in subjects with CED when compared to controls ${ }^{78}$, suggesting that diet induced thermogenesis did not show any energy saving, adaptive response in CED.

\section{Effects on physical activity}

The energy cost of daily physical activity of individuals with CED is not well established. The best measurements of daily PALs come from free-living experiments measuring TEE by the doubly labelled water method (DLW) ${ }^{79,80}$, and expressing the PAL as the ratio between the measured TEE and the BMR. Ideally, the PAL should be calculated taking into account the thermogenic component of the TEE, such that the PAL is the ratio of the TEE and the sum of BMR plus 10\% of the TEE (assuming the thermogenesis due to food to be about $10 \%$ of the TEE). However, it is simpler not to make this distinction, and to calculate PAL as TEE/ BMR. While there are a number of studies that have validated and measured TEE by the DLW method, these have been carried out in predominantly Western populations. In an Indian study in individuals with CED, TEE was measured $^{81}$ in urban and rural young males with CED. These measurements were compared with control well nourished (normal BMI), upper socio-economic class males. The PAL in the urban subjects with CED subjects was 1.5 , which was significantly lower than those in the normal BMI controls (1.8) and in the rural farmers (1.9). The high $\mathrm{PAL}$ in the rural farmers is similar to the even higher PAL (2.4) reported for rural Gambian men during intense agricultural work ${ }^{72}$, and to the high PAL measured in rural men (1.9) and women (2.2) as the ratio between energy 
intake and $\mathrm{BMR}^{82}$. These are also similar to the value of 1.9 for male agricultural workers from less developed countries estimated using Integrated Energy Indexes for different activities, apportioned into number of hours spent in those activities per day; however the calculated value for female agricultural workers was lower at $1.7^{83}$

The lower PAL observed in the Indian urban CED slum dwellers (who were manual labourers) was possibly due to long rest periods during their work, or due to intermittent work availability, or due to very sedentary activity during their leisure time. It could also be due to less spontaneous activity, or fidgeting. In a whole body calorimetric study of 24-hour energy expenditure with ad libitum activity (except for an hour of prescribed exercise) in low BMI Gambian men and normal BMI controls, it was observed that there were no differences in the TEE when adjusted for weight or FFM using analysis of covariance $^{65}$. However, the low BMI group had a slightly lower mean PAL (1.3) when compared to the controls (1.4), despite similar activity patterns. While this is a small difference, it is important to remember that fidgeting and the response to other small stimuli can raise the TEE by $10 \%^{84}$, and the reduction of superfluous movements may be one way of adapting to a low energy intake ${ }^{85}$. A similar conclusion may be drawn from a recent study which overfed normal weight individuals for 8 weeks, and found that two thirds of the increase in TEE could be accounted for non-exercise activity thermogenesis which is associated with fidgeting, maintenance of posture and other activities of daily living ${ }^{86}$. It is also interesting to speculate that the lower PAL of the individuals with CED could be due to their inherent smaller size, as it has been shown that the PAL of heavier individuals is greater than that of lighter individuals, for the same level of physical activity ${ }^{87}$. However, it can be argued that if the extra weight of heavier individuals was due to fat mass (which would not increase the BMR much), then the extra work of moving this fat would be reflected in the greater PAL of these individuals $^{88}$. As with the Indian labourers with CED and low PALs, an analogous situation has been observed in Guatemalan labourers, where men with significantly lower lean body mass (LBM) were able to complete the same amount of work compared to well-nourished men, but took much longer to do it ${ }^{89}$. Clearly, more studies are needed in this area, particularly paying attention to the motivation of the subjects during the study.

Work capacity and productivity are linked to the aerobic capacity of an individual, which in turn is dependent on the body weight, height and FFM. Therefore, nutritional status, by influencing the latter, would influence work capacity. For instance, work output was associated with poor anthropometric status in migrant adolescent agricultural workers ${ }^{90}$. In Colombian sugar cane cutters, work output was correlated with height, weight and LBM, as well as to the physical fitness of the subject in terms of his maximum $\mathrm{O}_{2}$ consumption $\left(\mathrm{VO}_{2} \max \right)^{91}$. This also demonstrates that the work output is related to both the present $\left(\mathrm{VO}_{2} \mathrm{max}\right)$ and the past (height) nutritional status. The $\mathrm{VO}_{2}$ max was also found to be progressively lower as the nutritional status of subjects' worsened $^{92}$. In Indian industrial workers, good correlations were found between weight, BMI and work capacity in workers with a low $\mathrm{BMI}^{93,94}$. Even in low intensity industrial work, it was found that productivity was associated significantly with weight, height and the LBM. In Guatemala, tall sugar cane cutters have also been shown to be more productive ${ }^{95}$, while Haddad and Bouis ${ }^{96}$ have also shown that height and not BMI was a significant determinant of wages. In Kenya, it was found that the BMI of men showed a relationship with household income, while this was not that evident in women ${ }^{97}$.

Ferro-Luzzi et $a l^{2}$ demonstrated that individuals with varying degree of CED spent fewer hours per day working than normal individuals in the same cultural milieu. Overall, the link between poor nutritional status and work productivity is complex, with several variables such as motivation, wage, the health status of the individual and absenteeism ${ }^{3}$.

Forearm grip strength has also been evaluated in urban and rural individuals with CED. Marginal malnutrition in Mexican boys is associated with reduced grip strength when compared with Mexican-Americans ${ }^{98}$. Studies in India have indicated that rural adults with CED have lower handgrip strengths, in absolute terms, as well as when corrected for forearm muscle area in comparison to wellnourished subjects ${ }^{99}$. However, more recent studies have indicated that urban adults with CED have reduced absolute handgrip strengths when compared to wellnourished subjects, but that these differences do not persist when corrected for differences in forearm muscle area or volume ${ }^{100}$. A lower $\mathrm{VO}_{2}$ max has been observed in marginally malnourished young men in Guatemala when compared to well-nourished men from higher socioeconomic backgrounds ${ }^{101}$, and in Indian individuals with CED when compared to normally nourished controls ${ }^{102}$; in these cases, the difference in $\mathrm{VO}_{2}$ max disappeared when corrected for the subjects' size and body compositions. In addition, it has been found that CED subjects also fatigue faster when subjected to standard laboratory isotonic and isometric exercise protocols than their well-nourished counterparts $^{100}$, although in other studies, there were no differences in endurance between undernourished and normal individuals ${ }^{103}$. Taken together, the data indicate that CED subjects have reduced skeletal muscle performance that is largely explained by the reduction in muscle mass, but may also be partly due to functional changes in skeletal muscle.

The anecdotal observation that subjects with CED do a lot of work with reportedly low energy intakes has led to the speculation that there may be some mechanical efficiency in CED subjects. Studies of young individuals with CED in a whole body calorimeter have suggested that 
the CED have reduced post-exercise oxygen consumptions, and return to their basal oxygen consumption faster than well nourished controls ${ }^{104}$. Other whole body calorimetric studies in young urban CED subjects have shown that they have a higher net mechanical efficiency during stepping ${ }^{102}$. However, Norgan and Ferro-Luzzi ${ }^{2}$ suggest that the high intensity stepping task would have had a high anaerobic component, thus explaining the apparently high net mechanical efficiency observed. Net mechanical efficiencies were not different between Gambian men with BMI < 18.5 when compared with normal BMI Gambian men ${ }^{65}$; similarly, Spurr et al. ${ }^{105}$ showed no significant difference in the delta efficiency of treadmill walking between well-nourished and marginally nourished boys. On the other hand, increased delta efficiency during cycling (up to an extent of 5\%) has been observed in normally nourished lactating women from economically deprived neighbourhoods in Colombia ${ }^{106}$. A muscular efficiency of this amount in women whose requirements are about $10 \mathrm{MJ} \mathrm{day}^{-1}\left(\sim 2400 \mathrm{kcal} \mathrm{day}^{-1}\right)$ would lead to energy savings of (assuming a PAL of 1.6) of about $0.2 \mathrm{MJ} \mathrm{day}^{-1}\left(\sim 50 \mathrm{kcal} \mathrm{day}^{-1}\right)$. The interpretation of these conflicting findings is limited because of the different methods of calculating mechanical efficiency; in addition, the energy saving due to these adaptive mechanisms is likely to be small. It is also possible that the (small) adaptive increase in mechanical efficiency in CED, if present, could be due to an increased percentage of slow twitch fibres, which are more efficient, and use fat as their primary fuel, a fact that may be important when glucose needs to be used sparingly. This may be due to the diminished thyroid status of the subjects with $\mathrm{CED}^{102}$, or due to the malnutrition itself $^{107,108}$. It must also be remembered that the CED subjects can reduce the energy cost of activity by simply economising their movements during work, as has been observed in the cost of sitting and standing, in African and Asian subjects ${ }^{109}$.

Subjects with CED can also reduce their energy expenditure by a variety of means related to their behaviour. Rural Guatemalan men with lower lean body and muscle mass took longer than their well-nourished counterparts to finish a task, although they completed the same quantum of work ${ }^{89}$. A similar finding was also observed in Kenyan road workers, where there was a significant relationship between the weight-for-height, and the time taken to complete a task ${ }^{110}$. In addition behavioural changes were also observed, in that these subjects spent a longer time in sedentary discretionary activities. The physical activities related to work and earning, of undernourished individuals in developing countries, seem to be maintained in spite of low BMIs, and the restriction of social or discretionary activities seems to be a survival strategy in these situations. Spontaneous physical activity may also be curbed, as was noted in the long-term energy deficient study of Biosphere $2^{21}$ as well as in calorimetric studies in Gambians ${ }^{65}$, where spontaneous activities measured by radar were lower in low BMI individuals. It appears that a low BMI and CED is associated with a decline in work output and discretionary activities. There is also an inability to work at a given pace and to maintain that pace throughout the day.

\section{Summary}

In summary, CED is an inadequacy in food to which individuals adapt, at some cost. These individuals are different from those studied in AED, as they have never 'lost' weight: they have simply grown less. They adapt to the decreased food energy by reductions in their TEE, linked mainly to a lower body size, and to their physical activity. The latter does not tend to be low; indeed it may be very high based on the work an individual is forced to do in order to survive, and these episodic or seasonal fluctuations in work demand and food availability may lead to fluctuations in body weight. Since individuals with CED have to work in order to survive, their physical activity may be normal or high depending on their economic and seasonal situation; however, this conceals an undesirable and unhealthy decline in social and discretionary components of their activity. It seems unlikely that there are any metabolic efficiencies in the activity of tissues in CED, nor in physical activity, although this latter has to be seen in the context of possible 'real-life' efficiencies, as have been observed in Kenyan women who can carry up to $20 \%$ of their body weight without increases in energy expenditure ${ }^{111}$.

\section{Morbidity and mortality with chronic energy deficiency} A study from India ${ }^{6}$ has shown that low BMI $(<16.0)$ is associated with an increased mortality rate of 32.5 deaths/ 1000 per year, when compared to a mortality rate of 12.1 deaths/1000 per year in normal (BMI > 18.5) individuals. These rates rose progressively as the BMI decreased. However, it is not clear whether the low BMI was a cause of death, or a consequence of other disease processes leading to death. There is also some concern that the $J$-shaped curve of Western morbidity/mortality rates in relation to BMI implies a higher death rate in thin adults ${ }^{112}$, although the cause of mortality in thin people may be due to other risks such as smoking, or illness related weight loss. In addition, it has been pointed out that the relationship between a low BMI and morbidity or mortality implies 'circularity', in that a low BMI can cause illness, and conversely, illness can cause a low BMI ${ }^{113}$. Given the close association between undernutrition and immune status ${ }^{114}$, it is likely that individuals with a low BMI would be more prone to infectious diseases, particularly in developing countries, and this may lead to a vicious cycle of disease and further undernutrition.

In terms of morbidity, Francois has shown that below a BMI of 17.6, a large amount of time was spent in bed due to sickness in a population of rural adults from Rwanda ${ }^{3}$. In rural Sarawak, it was found that the number of symptoms of sickness was associated with the BMI in men, but not in 
women $^{115}$. In Brazil, data from the National Health and Nutrition survey demonstrated that a plot of days sick (over a 2-week period prior to interview) with the BMI gave a $U$-shaped curve, similar to the mortality vs. BMI curve in Western populations ${ }^{116}$. Below a BMI of 17.0, there was a sharp increase in the number of sick days. In a group of poor Indian men, retrospective morbidity was two to three times higher in those men with a BMI less than $16^{117}$. The BMI was also a better discriminator of retrospective morbidity than other anthropometric variables. However, in a study of four different populations with self reported illness, the BMI was not found to be significantly related to illness in terms of using a BMI of $18.5 \mathrm{~kg} \mathrm{~m}^{-2}$ as the cut-off between groups, although the authors recognised that there were many other factors, particularly activity, that determined the thinness of adults ${ }^{113}$.

\section{Effect of re-feeding in energy deficiency}

It is well known that the re-feeding of semi-starved individuals leads to an increase in body weight, particularly fat, as was described in the Minnesota study $^{20}$. In the Biosphere 2 study as well, individuals who had been on an energy restricted diet for 2 years and had lost $\sim 15 \%$ of their body weight, went on to reestablish their body weight after consuming an ad libitum diet for 6 months after the study ${ }^{21}$. Dullo et al. ${ }^{118}$ have concluded that the body fat stores are hardwired in the system as a set point, or 'fat stores memory', thus ensuring that the same fat store is quickly regained on re-feeding after semi-starvation. They also suggest that this set-point mechanism operates through a feedback reduction in thermogenesis, such that the fat stores are regained in the quickest possible time, and therefore, an advantage in situations where food availability is uncertain ${ }^{50}$. In addition, they concluded that the hyperphagia observed on re-feeding after semi-starvation, was linked to both the fat and FFM loss with semi-starvation ${ }^{118}$.

The important question is what happens when those who have never lost weight, such as the chronically energy deficient, are supplementally fed? A 45-day supervised repletion of energy (but with low protein of $5.7 \%$ ) has been studied in adults with a mean BMI of about $16.0 \mathrm{~kg} \mathrm{~m}^{-2} 119$. It is not clear what the energy intake of the subjects was prior to the study, however they were farm labourers with presumably low energy intakes, and probably weight stable at the time, since they were able to work on these intakes. After the 45 day supplementation period, the body weight of the subjects increased by about $1.8 \mathrm{~kg}(\sim 4 \%)$, while their fat mass increased by about $5.1 \mathrm{~kg}$ (percent body fat increased from 19.7 to $29.7 \%$ ). This meant a decline in their FFM, which reduced from 34.5 to $32.2 \mathrm{~kg}$; the muscle and visceral compartment also showed a decline from 10.1 to $9.6 \mathrm{~kg}$, and from 4.7 to $3.0 \mathrm{~kg}$, respectively. The total body water (TBW) also decreased; thus, these bi-directional changes combined such that there was only a modest increase in body weight. The important point to note in these data is the relatively large increase in body fat, which however, was not detected in the triceps or subscapular skinfolds, and hence must have been at other subcutaneous or intra-abdominal sites. This pattern of weight gain was altered once the subjects were given protein repletion in addition to their energy repleted $\operatorname{diets}^{119}$. When the protein intake was increased to about $2 \mathrm{~g} \mathrm{~kg}^{-1}$ per day (compared to about $0.6 \mathrm{~g} \mathrm{~kg}^{-1}$ per day at their habitual and energy repleted diets) in addition to the increased energy intake, FFM increased significantly, in terms of both muscle and visceral mass, and while body fat continued to increase, its rate of increase relative to the body weight change was slower. This suggests that a healthier pattern of weight gain can be achieved by attention to protein intake. Significant improvements in $\mathrm{VO}_{2}$ max after protein and energy feeding have been observed, due to an improvement in muscle mass, however this is not observed with energy supplementation alone ${ }^{103}$.

In a short term re-feeding study over 12 weeks, supplementing seven chronically energy deficient subjects with about $40 \%$ of their habitual energy intake, in the form of a corn-soya meal/oil/sugar mix (low protein at $7.5 \%, 52.5 \%$ carbohydrate and $40 \%$ fat), it was found that mean body weight increased by $1.9 \mathrm{~kg}$, or nearly $5 \%$ of their pre-supplementation body weight ${ }^{33}$. This was partitioned into an increase of 58\% in body fat, measured by skinfolds, and the rest in the FFM. Unfortunately, the change in each skinfold was not provided, such that it is not known whether this fat increase was truncal or appendicular. In addition, body fat was measured by the sum of four skinfolds, using Durnin and Womersley's prediction equation ${ }^{120}$; while this method has been validated in terms of a systematic error in these populations ${ }^{121}$, the random error is considerable, added to which are inter and intra-observational errors, and it should be emphasised that the skinfold method is a surrogate for body fat, but does not actually measure it. Out of the total weight gain, $1.3 \mathrm{~kg}(68 \%)$ was observed within the first 3 weeks, partitioned into a fat: FFM ratio of 46:54, while the remainder weight gain over the last 9 weeks of the study was $83 \%$ fat. The post-supplementation BMR increased significantly even after adjusting for the FFM (by about 19\%), while the respiratory quotient (RQ) rose significantly (Fig. 3). The increase in body weight was modest when compared to the energy supplementation, and the authors speculated that this was due either to a substitution in the diet, or, since this was a free living study, to an increase in work related activity and total daily energy expenditure. The modest weight change could also have been due to bi-directional changes in the size of different body tissue and water compartments $^{103}$. The increase in FFM (measured as the difference between body weight and fat measured by the 

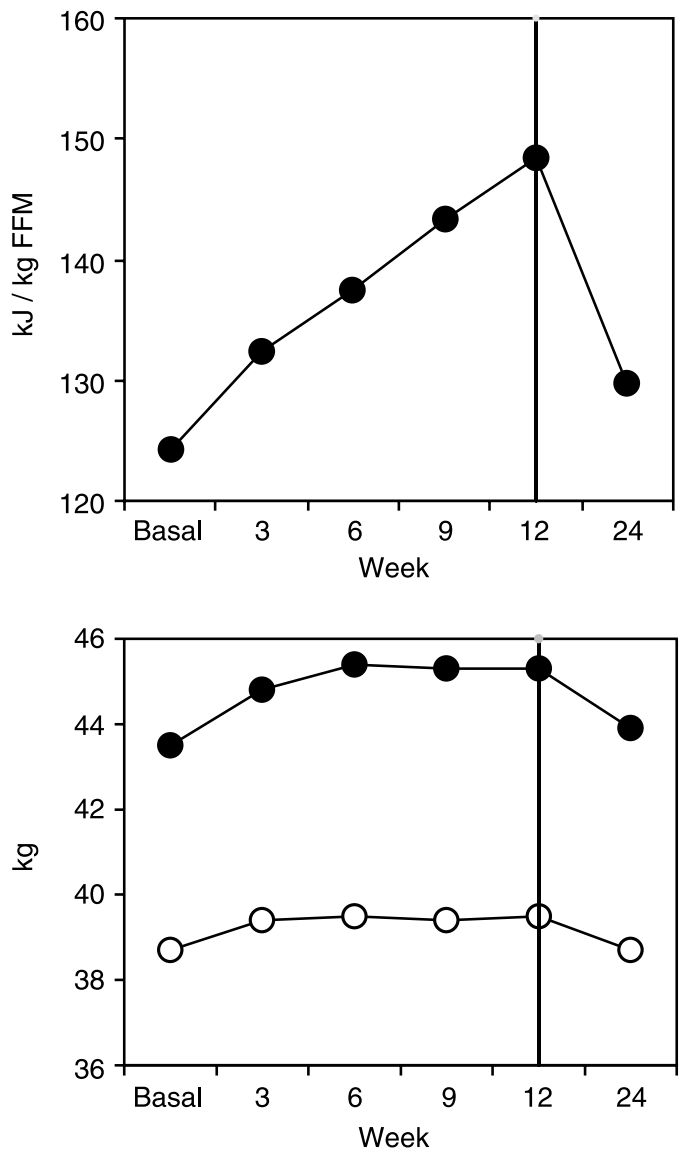

FFM (kg, lower box, filled circles = body weight, open circles $=$ fat free mass). BMR (kJ/kg FFM, upper box).

The vertical black line denotes the cessation of supplementation. See text for details.

Source: Drawn from data taken from Soares et al. ${ }^{33}$.

Fig. 3 Change in body weight and FFM and BMR during overfeeding of men with CED, and a subsequent 12-week period of normal diet

skinfold method) observed in the early re-feeding was not due to an increase in muscle mass, as the 24 hour creatinine excretion did not change $\mathrm{e}^{33}$, and it is possible that this could have been due to an increase in visceral or splanchnic mass, as has been observed before ${ }^{122,123}$, or due to changes in the hydration of the FFM. In these same subjects, noradrenaline stimulated and diet induced thermogenesis did not change with energy supplementation $^{78,124}$

If food supplementation is episodic, the question is what happens when the chronically energy deficient subjects return to their pre-supplemented state, as would happen with episodic food availability? This was also studied by Soares et $a l^{33}$ as a continuation of their experiment (above), 12 weeks after the supplementation of the subjects ceased, and while the subjects' energy intake (by dietary recall) remained the same as in the pre-supplemented state, their BMR adjusted for FFM was significantly lower than after 12 weeks of supplementation; interestingly, while the subjects lost
$1.4 \mathrm{~kg}$ body weight (out of $1.9 \mathrm{~kg}$ gained during supplementation), only $36 \%$ of this loss was fat. Admittedly, these changes in body fat mass were determined by the measurement of skinfold thickness, and no measurements in body water loss or hydration of fat free tissue were made. Therefore, with these caveats in mind, it can be assumed that there was a net gain of about $0.6 \mathrm{~kg}$ fat due this cycle of episodic supplementation over 6 months. This is analogous to the situation in re-feeding individuals after starvation, where much of the weight gain is fat.

The potential for the increase in fat stores on re-feeding raises important public health issues related to the epidemic of type 2 diabetes and coronary heart disease (CHD) in transitioning populations in developing countries, such as India ${ }^{125,126}$. This is based on several lines of evidence; first, populations in developing countries are undergoing remarkable transitions in their lives based on dietary practices (increased energy intake, substitution of coarse grains with refined cereals, and the use of increasing amounts of $\mathrm{fat}^{127}$ ). Economic transitions are being seen as well, in rural to urban migrations, the growth of an affluent middle class ${ }^{128}$, and the increase in the proportion of obese individuals from tribal to urban groups, and from lower to higher income groups?. Second, Asians and MexicanAmericans seem to have a higher amount of body fat at a given $\mathrm{BMI}^{16}$. Third, the main anthropometric correlate of both diabetes and CHD is obesity, particularly of central distribution $^{129}$ and it has been shown that the higher BMI and central obesity (Waist-Hip Ratio, WHR) is associated with a higher prevalence of diabetes ${ }^{130}$ in urban Indians, and also explained the higher risk of insulin resistance in migrant Indians compared to white Caucasians in the $\mathrm{UK}^{129,131}$. Fourth, in a study of maternal nutrition and foetal growth it was shown that babies born in India were thinner and lighter when compared to those in the developed world, but had subscapular skinfolds which were 93\% of Western babies, suggesting that their fat stores were not diminished ${ }^{132}$. Fifth, it is thought that insulin resistance is related to circulating concentrations of the proinflammatory cytokines secreted by adipose tissue such as TNF $\alpha^{133}$, and in conditions where there is a higher possibility of sub-clinical infections, this may be a significant factor in the development of insulin resistance. Finally, there is also preliminary evidence that adipose tissue, in addition to secreting cytokines and leptin, also elaborate a protein named resistin, which may have a role in increased insulin resistance ${ }^{134}$. A common thread that runs through these observations is the role of accumulated body fat in general, as well as of its location, and taken together point to a dual problem particularly in developing countries: while CED will remain a major public health problem, economic growth and development may lead to an equally large burden of chronic disease. Appropriate preventive measures that avoid excessive nutrient intake, as well as the aggressive promotion of healthier lifestyles, will be needed. 


\section{Effect of energy deficiency in the elderly}

There is an increase in the number of elderly in most populations due to a longer life expectancy, but little data on the effects of energy deficiency on such individuals in the long-term, or in chronically energy deficient elderly subjects. The BMR of elderly individuals reduces with progressive age, and is less than that of young adults $^{135-137}$. The decline in TEE is of the order of 0.69 and $0.43 \mathrm{MJday}^{-1}$ per decade in men and women, respectively, of which $44 \%$ is accounted for by a decrease in BMR, $46 \%$ by a decrease in physical activity, and $10 \%$ by a decline in thermogenesis ${ }^{138}$. The decrease in BMR may be greater in sedentary elderly than in habitually exercising elderly ${ }^{139}$ and this decrease is not completely explained by the reduction in the $\mathrm{FFM}^{13}$. The decline in thermogenesis in the elderly has been demonstrated for food $^{140}$ as well as for $\beta$-adrenergic agonists ${ }^{141}$ and is not tissue specific. It has also been found that elderly men did not increase their maintenance energy expenditure as much as young men in response to overfeeding of about $4 \mathrm{MJ} \mathrm{day}^{-131}$, and are therefore more liable to store the extra energy intake as fat. These observations suggest that the elderly may have lower energy expenditure, and in the face of higher energy intake, may be at increased risk for fat accumulation and chronic diseases such as type 2 diabetes and cardiovascular disease. The FAO/WHO/ $\mathrm{UNU}^{61}$ recommendation suggested that the energy requirement of the elderly was lower than in young adults and set it at 1.51 times the BMR for persons whose age was greater than 50 years.

However, studies on the activity patterns of elderly individuals from Western societies have demonstrated that they have a high physical activity, and therefore a higher than expected requirement at a mean value for both genders, of 1.68, when available values for TEE were adjusted upwards by $2 \%$ to account for a lower fractionated water loss in older people ${ }^{31}$. While it is known that the elderly constitute a heterogenous group and that it may be wrong to make generalisations on the basis of selected studies for the entire group, the observation of Roberts ${ }^{31}$ raises concerns of energy deficiency in the elderly if they are unable to compensate this relatively high-energy expenditure. In addition to the heterogeneity of the elderly group, it must be remembered that there may be a selection bias in the recruitment of elderly subjects, since those elderly who are concerned and curious about their health, with healthier lifestyles, may be the easiest to recruit. Addressing this bias, Fuller et $a l .{ }^{142}$ showed that the daily energy expenditure in elderly men over the age of 75 years was 1.5 times the BMR, which was similar to the $\mathrm{FAO} / \mathrm{WHO} / \mathrm{UNU}^{61}$ recommendation, albeit with substantial inter-individual variation. The potential negative energy balance in the elderly is also of concern because aging is associated with a decrease in body protein content, which is more marked in the muscle compartment ${ }^{143}$, and which would be accelerated in the presence of energy deficiency.

A 3-week underfeeding trial of elderly subjects, by about $3.4 \mathrm{MJ} \mathrm{day}^{-1}$ showed that they reduced their resting energy expenditure (REE) and TEE to the same degree as normal young subjects subjected to an energy restriction of similar magnitude of about $3 \mathrm{MJ}$ day $^{-131}$. The decline in REE was greater than what would have been expected from the weight loss alone, as is expected in acute undernutrition, but this decline was smaller than what was observed in the younger adults, and a plot of the change in REE to the change in energy intake revealed that the younger men had a higher slope suggesting a greater unit change in REE per unit change in energy intake ${ }^{144}$. No significant effects of age were observed in the maintenance (average of resting and postprandial energy expenditure) or TEE. In contrast to these findings, it was found that elderly men did not increase their energy expenditure as much as young men, in response to overfeeding of about $4 \mathrm{MJ}_{\text {day }}{ }^{-1145}$. This suggested that the elderly were likely to be predisposed to a greater adiposity during cycles of over and under-eating. A longer-term study of underfeeding by about $3.7 \mathrm{MJ} \mathrm{day}^{-1}$ for 6 weeks showed that the older individuals lost greater amounts of weight than their younger counterparts ${ }^{146}$. These elderly subjects also reported a significantly lower frequency of hunger during underfeeding, and during a follow up period of 6 months of ad libitum feeding did not regain their lost weight. It is thought that aging is associated with a significant impairment in the control of food intake in response to prior changes in energy intake $\mathrm{e}^{147}$.

The preceding discussion highlights two important issues: firstly that the elderly are more likely to put on weight during overfeeding. The weight gain may also be mainly fat, as it has been shown that the elderly tend toward a higher 24-hours RQ as they age, suggesting that they utilise less (and hence, store more) fat than their younger counterparts ${ }^{148}$. This study is particularly noteworthy as it assessed 24-hours RQ in a longitudinal design, over a gap of 7 years in the same subjects, thereby controlling for genetic differences. Secondly, the elderly are unable to match their energy intake to their output, particularly in underfed states. This is also of importance in elderly with chronic disease, where energy deficiency exists in spite of a decrease in physical activity, due to a reduction in energy intake ${ }^{149,150}$. In chronically energy deficient populations, there is a decrease in BMI after the age of $50^{9}$. Even in acutely unstable situations where food energy availability was low, as in refugee camps, the prevalence of undernutrition, measured by BMI was higher among individuals above age 60, without gender effect $^{151}$. There is no data available on the energy expenditure, and therefore requirement of chronically energy deficient elderly populations, both urban and rural. Importantly, the potential reduction in energy expenditure in CED in the elderly could have effects on the quality of life as shown in Western studies ${ }^{142}$, as well as on morbidity 
due to the accompanying sarcopenia, and on appetite. Given the documented changes in autonomic nervous activity with aging ${ }^{152,153}$, it would be interesting to study the interaction of undernutrition (along with the possible decrease in sympathetic nervous system activity) and aging on autonomic nervous activity and its possible implications in postural and postprandial hypertension in the elderly.

\section{Energy deficiency in pregnancy and lactation}

Energy deficiency is highly prevalent among adults in developing societies because of chronically low energy intakes in combination with high-energy expenditure related to work. Women, in addition to this already existing nutritional stress, spend a large portion of their lives meeting additional high energy demanding physiological conditions such as pregnancy and lactation. In Africa and Asia, where CED is more prevalent, most women are pregnant or lactating for 35-48\% of their reproductive years ${ }^{154}$. It has been said that such reproductive stresses, when coupled with under-nutrition, lead to a maternal depletion syndrome, which in turn has adverse effects on the progress of pregnancy, pregnancy outcomes, lactation performance, and subsequent maternal and child health ${ }^{155}$.

A reduction in fecundity in undernourished women has been described to be the first reproductive mechanism that ensures a reproductive cycle is not initiated until sufficient fat reserves are available to protect against possible acute food shortages ${ }^{156}$. The onset and maintenance of menstrual cycles are each reportedly associated with a critical fat store ${ }^{157}$. This suggests that there is a body weight and/or composition associated with optimal reproductive success. Undernourished women frequently have delayed menarche, highly frequent irregular and anovulatory cycles, complete cessation of menstruation and early menopause ${ }^{158}$. Post-partum infertility is a second protective mechanism that helps to ensure that the mother does not have to sustain the dual costs of simultaneous pregnancy and lactation ${ }^{156}$. The third mechanism involves the utilisation of body fat stores to subsidise the costs of pregnancy and lactation, particularly in times of acute food shortages.

\section{Pregnancy}

In addition to the above protective mechanisms, there is good evidence that the costs of deposition and maintenance of additional tissue during pregnancy, in undernourished women, may be significantly offset by adaptive readjustments in other components of the maternal energy budget ${ }^{159,160}$. Hytten ${ }^{161}$ estimated the total energy requirement for an entire pregnancy to be $335 \mathrm{MJ}$ (translating to an additional energy intake of 1.2 $\mathrm{MJ} \mathrm{day}^{-1}$ ), of which $150 \mathrm{MJ}$ are required for increases in basal metabolism, and the remaining for tissue deposition and for the conversion of dietary energy to metabolisable energy. No allowance was made for energy costs of physical activity. This figure of $335 \mathrm{MJ}$ was arrived at with an expected maternal weight gain of $12.5 \mathrm{~kg}$ for the entire duration of pregnancy.

The two main areas where major energy savings could occur are basal metabolism and physical activity. Since basal metabolism constitutes $70-80 \%$ of total daily energy expenditure the potential for energy-sparing adaptations in this component are very high. To date, none of the carefully carried out studies on energy requirements during pregnancy has used women who are truly undernourished (BMI <18.5). However, studies have been conducted on marginally undernourished subsistence farming women in the Gambia where food shortages are very common.

Data from the earlier of the Gambian studies suggested a link between maternal energy sufficiency and the metabolic response during pregnancy ${ }^{162}$. Women in this study were divided into two groups, one of which received an energy-dense dietary supplement during pregnancy and the other un-supplemented. In both the un-supplemented and supplemented groups, BMR was lower at 3 months gestation than at conception. The BMR in the un-supplemented group was significantly lower than that of the supplemented group at 3 months gestation. Thereafter BMR rose until term in both groups, but to a point considerably lower than that anticipated. Overall, the supplemented group showed a significantly greater increase in BMR than the un-supplemented women suggesting that the energy cost of pregnancy varied in response to energy supply. These energy-sparing adaptive patterns produced mean maintenance costs for pregnancy of $-45 \mathrm{MJ}$ in un-supplemented women and $+4 \mathrm{MJ}$ in the supplemented subgroup as opposed to $150 \mathrm{MJ}$ in well-nourished women.

A recent study on similar Gambian women by Poppitt et al. ${ }^{160}$ supported the findings of the earlier study and showed that women were able to maintain an almost constant expenditure by reducing the components of maternal expenditure. Many women were able to completely cover the increase in maintenance expenditure that occurred in the second half of gestation by a reduction in BMR during early pregnancy. This was followed by only a small increase in basal metabolism during the rest of pregnancy. The cumulative maintenance expenditure of the group, measured up to 36 weeks gestation, was only 8.7 MJ. This increased to $26.5 \mathrm{MJ}$ when the data were extrapolated to include the final 4 weeks of pregnancy.

In the Gambian women, changes in BMR during pregnancy could not be attributed simply to changes in weight and LBM but were caused by mass-specific changes in metabolism. Even under the strong constraints of food intake and a high workload there was a large amount of inter-subject variability both in the increase of weight, LBM, and fatness during pregnancy and also in 
the pattern of metabolic depression. Although the change in BMR was not influenced by the nutritional status of the women before they became pregnant, changes in weight, LBM, and fat mass had a significant effect on BMR. Both the Gambian studies confirmed that large energy-sparing adaptations occurred in rural Gambian women and were manifested predominantly as a depression of BMR.

Maintenance costs in both these studies were far below group mean values from 112 to $218 \mathrm{MJ}$ and from 79 to $143 \mathrm{MJ}$ for well-nourished women in developed countries and other developing countries, respectively ${ }^{163-172}$.

A reduction in physical activity has long been postulated to be the most important, and in some cases the only, mechanism by which undernourished women are able to reduce their energy expenditure during pregnancy and thereby complete pregnancy with only a small increment in food intake. Time allocation is a measure of behavioural choice with respect to physical activity. In the Gambia ${ }^{173}$, women spent more time in bed during pregnancy and less time on light/moderate household work. The strictly controlled calorimeter protocol in the Gambian study by Poppitt et al. ${ }^{160}$ showed no significant differences, between serial measurements during pregnancy, in energy expended during periods of activity. They have suggested that the fact that energy expended during exercise did not increase in line with the increases in weight suggests energy savings during these periods. The calculations of energy savings for women from Keneba village amounted to $0.307 \mathrm{MJday}^{-1}$ during the dry season and $0.342 \mathrm{MJ} \mathrm{day}^{-1}$ during the wet season. However, these were far less than the energy spared by the depression in basal metabolism. In the Philippines ${ }^{166}$, women spent more time sitting, lying down and on light housework during late pregnancy. This compensated for less time spent on moderate and heavy housework. In a study conducted in Colombia, PALs were lower in the second and third trimesters of pregnancy with the women spending more time on energy saving activities and less time on energy demanding activities ${ }^{174}$. Although these studies do not give conclusive data on how much energy is saved by changing activity patterns during pregnancy, it is clear that diminished physical activity plays a major role in the energy balance equation during pregnancy.

\section{Pregnancy outcome}

Women in many developing countries achieve a successful outcome to pregnancy in spite of being chronically undernourished and are able to maintain a consistently high level of human reproductive performance in the face of nutritional deprivation. Indicators of maternal nutritional status which contribute to low birth weight (LBW, $<2.5 \mathrm{~kg}$ ) of the infant have been estimated to be maternal height, pre-pregnancy weight, gestational weight gain, energy intake, energy expenditure, work and physical activity $^{175}$. The mean birth weights of the infants in some of the studies mentioned earlier were between 2.89 and
$3.46 \mathrm{~kg}$, well above $2.5 \mathrm{~kg}^{163-172}$. Women from Holland who were tallest and heaviest had the heaviest babies while women from the Philippines who were the shortest and lightest had the lightest babies. Although women from the Gambia were taller and heavier than Thai women, their BMI was virtually identical, as were the birth weights of their infants.

A high incidence of LBW babies has been reported in mothers with low pre-pregnant BMI and/or 24-h post partum BMI in several studies ${ }^{7,176-178}$. Data from the National Institute of Nutrition in India ${ }^{179}$ revealed that $44 \%$ of women who were of low BMI $(<18.8)$ had LBW infants, compared to $32 \%$ in women with BMIs (18.8 and 23.2), and $19 \%$ of women with BMI $>23.2$. Naidu and Rao ${ }^{180}$ found the odds ratio for LBW among Indian mothers to be three times more in severe CED (chronically energy deficient) groups compared to normal BMI groups; mean birth weights showing definite differences between BMI classes $-2.5 \mathrm{~kg}$ in the grade III CED and $2.8 \mathrm{~kg}$ in the normal BMI group. Abraham and $\operatorname{Laros}^{181}$ found maternal BMI to have a significant independent effect on birth weight. Birth weights have been consistently found to be lower with low BMI $(<18.5)$ regardless of the weight gain of the mother during pregnancy ${ }^{176,182}$. Allen et al. ${ }^{177}$ showed an increase in the gradient in mean birth weight associated with increasing prepregnant BMI even within the normal range of maternal BMI.

\section{Lactation, maternal post-partum BMI and child growth}

Lactation requires much more energy than pregnancy, with 1 month's lactation being equivalent to the full cost of pregnancy. The major determinant of the extra energy needed during lactation is the energy cost and production of an average daily milk volume of $750-850 \mathrm{ml}$ at an estimated $80-90 \%$ rate of efficiency. This translates into a maternal need for an additional 2.1-2.3 MJ (500$550 \mathrm{kcal}) / \mathrm{d}^{61,183}$. For these requirements to be met, women will either have to increase their food intake or mobilise maternal energy reserves, particularly those laid down during pregnancy or conserve energy through the operation of adaptive mechanisms.

The up to date evidence indicates that milk energy output will be maintained within the expected range in undernourished lactating mothers although studies conducted in the Gambia and Bangladesh show that negative energy balance imposed on low body energy reserves could impair lactation performance ${ }^{184,185}$. The critical point of negative energy balance coupled with a certain low energy reserve at which milk output might be affected is currently not known. The volume of milk ingested during the first 6 months post-partum from lactating marginally undernourished (mean BMI $=19.0$ ) poorincome Indian women ranged between 623 and $776 \mathrm{ml}^{186}$. The milk outputs recorded in this study were higher than those earlier reported ${ }^{187,188}$. In a recent study conducted 
on low-income well-nourished mothers in urban Honduras, the average breast milk volume ranged from $797 \mathrm{~g} \mathrm{day}^{-1}$ at 4 months to $745 \mathrm{~g} \mathrm{~d}^{-1}$ at 6 months ${ }^{189}$.

There is also limited evidence of substantial weight loss during lactation in developing country women. In a study carried out in rural India, Prema et al. ${ }^{190}$ reported that maternal weight loss during 18-24 months of lactation averaged only $2 \mathrm{~kg}$ in spite of energy intakes of only 4.6 MJ $(1100 \mathrm{kcal}) / \mathrm{d}$. It has also been reported that Bangladeshi women maintain body weight through 30 months of lactation $^{191}$. Recent studies also show very modest weight losses during lactation ${ }^{185,192}$. However, Gambian women during the rainy 'hungry' season lost $0.74 \mathrm{~kg}$ per month. The observed fat-mass losses over the first 6 months of lactation in many well-nourished populations are often substantially smaller ${ }^{171,192-194}$ than the supposed $2-4 \mathrm{~kg}$ fat mobilisation, suggesting that significant weight losses are not obligatory during lactation.

Studies involving longitudinal measurements of BMR during lactation from both developed and developing countries show mixed results ${ }^{171,193-195}$, and there is still no clear consensus on whether RMR remains unchanged, is lowered or elevated during lactation ${ }^{183}$. A recent review of all the available data by the IDECG committee revealed that in Western countries women tend to decrease total physical activity during lactation, especially with respect to moderate and discretionary activity whereas in developing countries reductions in activities during lactation are not apparent $^{183}$.

The post-partum BMI of women has also been linked with growth in their infants and young children. A study in Indonesia reported an upward gradient in infant weight and weight gain in the first 6 months with increasing postpartum BMI of women in low as well as normal birth weight categories ${ }^{178}$. The mean weight-for-height of $<5$ year-old children was significantly different in groups of mothers with varying BMI in a study in Brazzaville; mothers with low BMI having a higher proportion of children with lower mean $Z$-scores ${ }^{196}$. Low mean BMIs in Indian adults in a rural household were linked with wasting and stunting of their infants and young children ${ }^{180}$. Others have also shown a link between BMI of mothers and the degree of wasting in their children $^{177,178,197}$

\section{Summary}

It appears that in a marginally undernourished woman living under the constraints of a limited food supply and hard physical labour, except in extreme cases where there is a reduction in fecundity, major reductions in basal metabolism and behavioural changes in the form of diminished physical activity could meet most of the extra energy needed for pregnancy and allow the delivery of a viable infant. Women in many developing countries achieve a successful outcome to pregnancy in spite of being chronically undernourished. Birth weights of infants appear to be similar in both taller-heavier and shorterlighter women if their BMIs are identical. Maternal BMI is a better indicator of risk for LBW infants than maternal body weight or height alone. The evidence to date indicates that milk energy output will be maintained within the expected range in undernourished lactating mothers. The critical point of negative energy balance coupled with a certain low energy reserve at which milk output might be affected is currently not known. The link between the post-partum BMIs of mothers and the growth of their infants and children strongly suggest an intergenerational effect, low BMI mothers tending to have LBW babies and poorly growing infants. Improving the nutritional status of girls of this generation would certainly result in better-nourished children in the next generation.

\section{Energy deficiency in infants and children}

The effect of food deficiency in the growing infant or child in essence, is a decrease in growth rate. While energy deficits occur in association with other nutrient deficiencies such as protein, iron or zinc, it is probably a combined deficiency that limits growth ${ }^{198}$. It is thought that the term 'energy-nutrient' malnutrition should replace the earlier 'protein-energy' malnutrition in describing the aetiology of this condition ${ }^{199}$. The effects of this energynutrient deficiency range beyond growth retardation, to produce a 'syndrome of development impairment', which includes growth failure, delayed motor, cognitive and behavioural development, diminished immunocompetence and increased morbidity and mortality ${ }^{200}$. Food intake deficits also interact with the environmental presence of morbidity and infection to reduce growth. In the following section, no attempt has been made to use the specific terms applied to energy deficiency in adults; an acute energy (and nutrient) deficiency is equated with wasting, or a low weight for height, while a more chronic deficiency is equated with stunting, or a low height for age, and both these terms (wasting and stunting) imply a pathological process that has led to the weight loss or lack of height achievement, outside of terms such as thinness. While other anthropometric indices such as the BMI-for-age, or height-for-age (representing thinness or stunting, respectively) have been suggested to evaluate the nutritional status of adolescents, this report ${ }^{201}$ states that 'Although BMI has not been fully validated as an indicator of thinness or undernutrition is adolescents, it provides a single index of body mass, applicable to both extremes (of the BMI distribution)'. While it is being evaluated as an indicator of adult obesity ${ }^{202}$, adult cardiovascular mortality ${ }^{203}$, prevalence of undernutrition (although in this study the adult criteria for CED were used in adolescents ${ }^{204}$, and even in the maintenance of the BMI status of an individual through later childhood and adolescence $^{205}$, it was felt that the use of the BMI indicator 
for demarcating CED or undernutrition did not offer any advantage for the purpose of this review.

\section{Effects on anthropometry and metabolism}

The degree of deficiency can range from mild, with diminished growth rate and a decreased activity, to severe, with additional effects of body wasting, along with clinical and biochemical signs as shown in Table $2^{206}$. The decrease in growth rate results in a lower body size along with changes in body composition. In general, with severe undernutrition, fat and muscle tend to be lost the most ${ }^{29,34}$, followed by thoracic and abdominal organs, while the brain tends to be preserved (Table 1). The TBW increases $^{207}$, particularly in those children with oedema, and is mainly due to an increase in the extracellular water $^{208}$. The assessment of undernutrition, particularly of the mild or less severe type, is best performed by anthropometric indicators such as height for age, weight for age, and weight for height, although these indicators may be sensitive to a number of factors other than energy or protein deficits. These anthropometric indicators can be used as ' $Z$-scores' (the deviation of the observed value from the reference mean in standard deviation units of the reference population) or as the percentile value referring to the distribution of an indicator in the reference population. Usually, cut-off values for these indicators are either -2 SD below the reference mean or the third percentile of the reference population, below which there is sharp increase in the risk of death ${ }^{209}$.

The effect of energy deficiency on energy expenditure in infants and children is difficult to assess, because the measurement of the resting metabolic rate in children with undernutrition is difficult, since several of the conditions required for the measurement may be violated due to practical reasons. In addition, the presence or absence of oedema makes the adjustment for body weight or FFM difficult. The metabolic rate (adjusted for weight or active tissue mass) in malnourished children has therefore been shown to be decreased ${ }^{210-212}$, increased ${ }^{213}$, similar ${ }^{214}$ when compared to controls. The methodology for these measurements varies and since these are made on children, several adjustments to the otherwise strict BMR protocol, such as measuring metabolic rate about an hour after a feed, or with sedatives, or during sleep, are made. The metabolic rate measurement during recovery from malnutrition is increased ${ }^{212,213}$ and this is one of the

Table 2 Stages in the development of energy-protein malnutrition in the child

\begin{tabular}{|c|c|c|c|c|c|}
\hline & Activity & owth rates & $\begin{array}{l}\text { Biochemical } \\
\text { indicators }\end{array}$ & Body wasting & $\begin{array}{c}\text { Clinical } \\
\text { signs }\end{array}$ \\
\hline Mild & + & + & & & \\
\hline Moderate & ++ & ++ & + & + & \\
\hline Severe & +++ & +++ & +++ & +++ & +++ \\
\hline
\end{tabular}

Source: Data from Martorell ${ }^{206}$. important reasons why elevated metabolic rates in infant and childhood malnutrition are seen. Overall, it is difficult to assess the metabolic rate in children in terms of the paradigm for adults, due to a lack of information on chronic (or milder) undernutrition, as well as the technical problems referred to above.

The TEE measured by the doubly labelled water technique (DLW) in malnourished children aged 1-36 months, was lower than the FAO/WHO/UNU ${ }^{61}$ energy requirement, and the body weight was the primary determinant of the $\mathrm{TEE}^{215}$. Therefore, any reduction of TEE should primarily be a function of the reduction in body weight. However, more recently, an analysis of TEE measurements (by DLW) in infants from different regions shows that firstly, they are similar and secondly, that these measurements were generally lower than the FAO/WHO/ UNU recommendations ${ }^{61,216,217}$. The question of whether energy expenditure (in terms of BMR or TEE) reduces with energy deficiency, as an attempt to come into equilibrium with the reduced energy intake, remains unanswered in general. In well-nourished children at least, it appears that energy intake rather than energy expenditure is the important determinant of weight variability at 1 year of age $^{218}$. In older undernourished children (boys and girls) between the ages of 6-16, the TEE estimated by time and motion studies was lower ${ }^{219}$, although when the TEE of stunted or marginally malnourished children is expressed per unit body weight, it has been found to be higher than that of well-nourished children ${ }^{216}$. This could be due to an effect of body composition, in which case the PAL of these malnourished children should be similar to their wellnourished counterparts. In general this appears to be the case, except in boys and girls aged about $6-7$ years, where the PAL was also lower than in well-nourished individuals ${ }^{216}$. Alternatively, Torun et al. ${ }^{216}$ have suggested that in children who come from rural developing country backgrounds, the PAL could in fact be higher. On the other hand, studies on 1-3 year old undernourished children in Africa showed that they spent more time sitting and standing than walking and running, as compared to Western children ${ }^{220}$. It seems likely that the PAL of children is dependent on the geographical and social circumstances from which they come. Another factor is the age of these children, when they become contributors to household work or income, such that the time allocation of their activities is weighted toward more energetic or productive activities.

\section{Effects on behaviour and other outcomes}

The effects of energy or energy-protein deficits are not restricted to physiological and morphological changes, but extend to include behavioural (individual and interactive, or social) changes. These changes are subtler than the gross clinical picture of malnutrition seen in more severe types of food deficiency, but no less important when one considers the optimum development of the child's capabilities, and the development of human capital. 
While anthropometric and metabolic parameters are indicators of the nutritional status, it is important to remember that nutrition by itself is not the sole determinant of growth; similarly, a putative causality between nutrition and behaviour is to be viewed in the context of effects of variables that cluster in low-income environments.

It is also likely that long-term milder malnutrition (leading to stunting) is more highly related to the child's mental development than short-term severe deficiency, which results in wasting ${ }^{199}$. Several techniques are used in assessing the effect of malnutrition on development and behaviour and these include developmental scales, tests of general intelligence, measures of single dimensions of behaviour, as well as behavioural observations in natural settings, free play activities and school performance ${ }^{221,222}$. These have been reviewed in detail ${ }^{223}$, and it is clear that in many of these tests, undernourished children performed less well than normally nourished children (where nutritional status was measured by an anthropometric parameter), suggesting that overall, the undernourished child is at risk of a less than optimal development of their capabilities. There are concerns about the cross-cultural application of psychometric scales nonetheless; this important but subtle effect underscores the need for ensuring adequate nutrition and extending the concern for undernutrition beyond more easily measurable anthropometric and clinical indicators. Thus, cross sectional studies in several countries have found significant associations between height for age and IQ, cognitive function, psychomotor development and school achievement, even after adjusting for socio-economic conditions $^{199}$. Stunted young children also showed significantly more apathy, less enthusiasm and variety in exploring activities, and in general were less happy and tended to fuss ${ }^{224}$.

In later childhood such as preschool, cognitive development is affected by malnutrition, and benefited by supplementation in terms of broad measures of cognitive development ${ }^{225}$. The important question is whether supplementation of food, and more particularly energy, is of benefit in reversing these developmental deficits, in the short and long-term. Using a developmental model that assessed the impact of internal variables such as physical growth, motor development, motor activity and emotional regulation, as well as caregiver behaviour and exploration (variables that involved the subject and the environment) on cognitive outcomes in undernourished Indonesian children aged below 2 years, Pollitt and others ${ }^{226}$ showed that early energy supplementation of about $1 \mathrm{MJday}^{-1}$ along with micronutrients, resulted in clear beneficial effects on most of these variables. Cognitive performance in these children improved with the energy supplementation after 6 months of supplementation, while motor activity improved within 2 months, when compared to controls or children supplemented with mainly protein. There were also improvements in interest and motivation for play activities leading on to better verbal interaction, particularly in girls who were energy supplemented with about $1 \mathrm{MJ} \mathrm{day}^{-1227}$. In another study on stunted Jamaican children between 9 and 24 months of age, energy and protein supplementation $(3.15 \mathrm{MJ}$ or $750 \mathrm{kcal}$ and $20 \mathrm{~g}$ protein per day) along with psychosocial stimulation provided to the children for a relatively long period of 2 years, showed that children who received both treatments benefited the most, although there were independent beneficial effects of each treatment ${ }^{228}$. While it was not clear which nutrient specifically caused the beneficial effect, it is clear that undernutrition operates to slow growth and development by the nutrient deficiency interacting with a variety of environmental factors.

The effect of supplementing children early, may, in addition to immediate effects, have long-term effects, as was suggested by a study in Guatemala, where adolescents who were given energy and protein supplements as young children, performed better on psycho-educational testing and reaction time responses than adolescents who were given energy supplements alone $^{229}$. Significantly, there was an interaction with socioeconomic status, and the benefits were greatest among children from the poorest homes.

\section{Summary}

The prevalence of childhood malnutrition is still high in developing countries, and is probably due to mixed dietary deficiencies. Malnutrition leads to recognisable anthropometric and clinical characteristics, particularly in the more severe cases. There is also a reduction in immune function, which can interact with environmental factors particularly in poor environments, to further reduce growth due to food deficiency. Milder energy-nutrient deficiency leads to stunting, and is associated with several functional and behavioural consequences. Motor development is delayed and effects on cognitive development can result in a lower IQ with the consequences of deficient learning and lower school achievement. All these impact on the development of human capability. Importantly, these deficits are amenable to supplementation, in association with a better environment, and thus suggest that improving child nutrition is an important priority for long-term development. While suggesting adequate requirements and implementing policies for better child nutrition should in the long term result in better development, it should also be remembered that developing countries will eventually face a greater heterogeneity in nutrition related problems in terms of excess nutrition and chronic disease. Therefore, programmes aimed at meeting the energy and nutrient needs of undernourished populations should also ensure healthy diets and adequate physical activity patterns to prevent chronic disease in these populations. 


\section{Suggested recommendations for further research}

- Studies on PALs and TEE in chronically undernourished populations; to include a wide range of individuals as for instance, rural agricultural workers, urban slum dwellers, and manual labourers of both genders.

- Energy costs of culturally specific physical activities need to be determined.

- Measurements of productivity and work output in chronic undernutrition in real life situations.

- Measurement of metabolic and functional consequences of pregnancy and lactation in low BMI mothers and the impact of supplementation in these women.

- The delineation of the relative contributions of intrauterine nutritional deficits and nutritional deficits during infancy on subsequent physiology and behaviour.

- Assessment of the response of supplementation in chronically undernourished adults, metabolic and physiological, with a view to understanding the development of chronic disease.

- Studies to better demonstrate the interaction between malnutrition and behaviour, as well as specifically delineate interactions among geographically and culturally appropriate external variables and nutrition.

- Behavioural studies in undernourished children, particularly at later stages, such as school going children of both genders, including the impact of supplementation.

- Investigations into the metabolic and functional consequences of adolescent and elderly chronically energy deficient subjects.

\section{References}

1 Bisdee JT, James WPT, Shaw MA. Changes in energy expenditure during the menstrual cycle. British Journal of Nutrition 1989; 61: 187-99.

2 Ferro-Luzzi A, Sette S, Franklin M, James WPT. A simplified approach to assessing adult chronic energy deficiency. European Journal of Clinical Nutrition 1992; 46: 173-86.

3 Shetty PS, James WPT. Body Mass Index. A measure of chronic energy deficiency in adults. FAO Food and Nutrition Paper FAO No 56. Rome: Food and Agriculture Organization, 1994.

4 Martorell R. Child growth retardation: a discussion of its causes and its relationship to health. In: Blaxter K, Waterlow JC, eds. Nutritional Adaptation in Man. London: K John Libbey, 1985; 13-30.

5 Khosla T, Lowe CR. Indices of obesity derived from body weight and height. British Journal of Preventive and Social Medicine 1967; 21: 122-8.

6 Satyanarayana K, Rao SS, Radhaiah G, Reddy V. Body mass index and mortality rates. Nutrition News, National Institute of Nutrition, India 1991; 12.

7 Naidu AN, Neela J, Rao JP. Maternal body mass index and birth weight. Nutrition News, National Institute of Nutrition, India $1991 ; \mathbf{1 2}$

8 James WPT, Ferro-Luzzi A, Waterlow JC. Definition of chronic energy deficiency in adults. Report of a working party of the IDECG. European Journal of Clinical Nutrition 1988; 42: 969-81.
9 Reddy BN. Body mass index and its association with socioeconomic and behavioral variables among socioeconomically heterogenous populations of Andhra Pradesh, India. Human Biology 1998; 70: 901-17.

10 Collins S, Duffield A, Myatt M. Assessment of Nutritional Status in Emergency Affected Populations. Geneva, Switzerland: ACC/SCN Report, 2000.

11 Norgan NG. Interpretation of low body mass indices: Australian aborigines. American Journal of Physical Anthropology 1994; 94: 229-37.

12 Norgan NG. Body mass index and nutritional status: the effect of adjusting body mass index for the relative sitting height on estimates of the prevalence of chronic energy deficiency, overweight and obesity. Asia Pacific Journal of Clinical Nutrition 1995; 4: 137-9.

13 Norgan NG, Ferro-Luzzi A. Weight-height indices as estimators of fatness in men. Human Nutrition Clinical Nutrition 1982; 36C: 363-72.

14 Forbes GB, Reina JC. Adult lean body mass declines with age: some longitudinal observations. Metabolism 1970; 19: 653-63.

15 Norgan NG. Population differences in body composition in relation to the body mass index. European Journal of Clinical Nutrition 1994; 48(Suppl. 3): 10-25.

16 Wang J, Thornton JC, Russell M, Burastero S, Heymsfield $\mathrm{SB}$, Pierson R. Asians have a lower body mass index (BMI) but higher percent body fat than do whites: comparisons of anthropometric measurements. American Journal of Clinical Nutrition 1994; 60: 23-8.

17 Gallagher D, Visser M, Sepulveda D, Pierson RN, Harris T, Heymsfield SB. How useful is body mass index for comparisons across age, sex and ethnic groups? American Journal of Epidemiology 1996; 143: 228-39.

18 Deurenberg P, Westrate JA, Seidell JC. Body mass index as a measure of body fatness: age and sex prediction formulas. British Journal of Nutrition 1991; 65: 105-14.

19 Norgan NG, Ferro-Luzzi A. Human adaptation to energy undernutrition. In: Fregly MJ, Blatteis CM, eds. Handbook of Physiology: Section 4. Environmental Physiology Volume II. New York: Oxford University Press for the American Physiological Society, 1996; 1391-409.

20 Keys A, Brozek J, Henschel A, Mickelson O, Taylor HL. The Biology of Human Starvation. St Paul: University of Minnesota Press, 1950; 303-39.

21 Weyer C, Walford RL, Harper IT, Milner M, MacCollum T, Tataranni PA, Ravussin E. Energy metabolism after $2 \mathrm{y}$ of energy restriction: the Biosphere 2 experiment. American Journal of Clinical Nutrition 2000; 72: 946-53.

22 Friedl KE, Moore RJ, Martinez-Lopez LE, Vogel JA, Askew EW, Marchitelli LJ, Hoyt RW, Gordon CC. Lower limit of body fat in healthy active men. Journal of Applied Physiology 1994; 77: 933-40.

23 Friedl KE. Variability of fat and lean tissue loss during physical exertion with energy deficit. In: Kinney JM, Tucker HN, eds. Physiology, Stress and Malnutrition: Functional Correlates, Nutritional Intervention. Philadelphia: Lippincott-Raven Publishers, 1997; 431-50.

24 Hammer RL, Barrier CA, Roundy ES, Bradform JM, Fisher AG. Calorie restricted low fat diet and exercise in obese women. American Journal of Clinical Nutrition 1989; 49: 77-85.

25 Dulloo AG, Jacquet J. Adaptive reduction in basal metabolic rate in response to food deprivation in humans: a role for feedback signals from fat stores. American Journal of Clinical Nutrition 1998; 58: 599-606.

26 Grande F, Anderson T, Keys A. Changes in the basal metabolic rate of man in semistarvation and refeeding. Journal of Applied Physiology 1958; 12: 230-8.

27 Cahill GF. Starvation in man. Clinics in Endocrinology and Metabolism 1976; 5: 397-415. 
28 Webb P, Abrams T. Loss of fat stores and reduction in sedentary energy expenditure from undereating. Human Nutrition Clinical Nutrition 1983; 37: 271-82.

29 Elia M. Organ and tissue contribution to metabolic rate. In: Kinney JM, Tucker HN, eds. Energy Metabolism. Tissue Determinants and Cellular Corollaries. New York: Raven Press, 1992; 61-72.

30 Webber J, Macdonald IA. The cardiovascular, metabolic, and hormonal changes accompanying acute starvation in men and women. British Journal of Nutrition 1994; 71: 437-47.

31 Roberts SB, Fuss P, Heyman MB, Dallal GE, Young VR. Effects of age on energy expenditure and substrate oxidation during experimental underfeeding in healthy men. Journals of Gerontology. Series A, Biological Sciences and Medical Sciences 1996; 51: B158-66.

32 Elia M. Tissue distribution and energetics in weight loss and undernutrition. In: Kinney JM, Tucker HN, eds. Physiology, Stress and Malnutrition: Functional Correlates, Nutritional Intervention. Philadelphia: Lippincott-Raven Publishers, 1997; 383-411.

33 Soares MJ, Kulkarni RN, Piers LS, Vaz M, Shetty PS. Energy supplementation reverses changes in the basal metabolic rates of chronically undernourished individuals. British Journal of Nutrition 1992; 68: 593-602.

34 Reeds PJ, Jackson AA, Picou D, Poulter N. Muscle mass and composition in malnourished infants and children and changes seen after recovery. Pediatric Research 1978; 12: $613-8$.

35 Garby L, Lammert O. An explanantion for the non-linearity of the relationship between energy expenditure and fat free mass. European Journal of Clinical Nutrition 1992; 46: 235-6.

36 Shetty PS. Physiological mechanisms in the adaptive response of metabolic rates to energy restriction. Nutrition Research Reviews 1990; 3: 49-74.

37 Shetty PS. Adaptation to low energy intakes: the responses and limits to low intakes in infants, children and adults. European Journal of Clinical Nutrition 1999; 53(Suppl. 1): $\mathrm{S} 14-\mathrm{S} 33$.

38 Zhang Y, Proneca R, Maffei M, Barone M, Leopold L, Friedman JM. Positional cloning of the mouse obese gene and its human homolog. Nature 1994; 372: 425-32.

39 Mistry AM, Swick AG, Romsos DR. Leptin rapidly lowers food intake and elevates metabolic rates in lean and ob/ob mice. Journal of Nutrition 1997; 127: 2065-72

40 Porter RK, Andrews JF. Effects of leptin on mitochondrial 'proton leak' and uncoupling proteins: implications for mammalian energy metabolism. Proceedings of the Nutrition Society 1998; 57: 455-60.

41 Grinspoon S, Gulick T, Askari H, Landt M, Lee K, Anderson E, Ma Z, Vignati L, Bowsher R, Herzog D, Klibanski A. Serum leptin levels in women with anorexia nervosa. Journal of Clinical Endocrinology and Metabolism 1996; 81: $3861-3$.

42 Polito A, Fabbri A, Ferro-Luzzi A, Cuzzolaro M, Censi L, Ciarapica D, Fabbrini E, Giannini D. Basal metabolic rate in anorexia nervosa: relation to body composition and leptin concentrations. American Journal of Clinical Nutrition 2000; 71: 1495-502

43 Bouchard C, Tremblay A. Genetic influences on the response of body fat and fat distribution to positive and negative energy balances in human identical twins. Journal of Nutrition 1997; 127: S943-7.

44 Bouchard C, Tremblay A, Despres JP, Theriault G, Nadeau A, Lupien PJ, Moorjani S, Prud'homme D, Fournier $G$. The response to exercise with constant energy intake in twins. Obesity Research 1994; 2: 400-10.

45 Macdonald IA, Bennett T, Sainsbury R. The effect of a 48 hour fast on the thermoregulatory responses to graded cooling in man. Clinical Science 1984; 67: 445-52.

46 Mansell PI, Macdonald IA. The effect of underfeeding on the physiological responses to food in normal weight women. British Journal of Nutrition 1988; 60: 39-48.

47 Macdonald IA, Mansell PI. The effect of seven days underfeeding on the thermoregulatory responses to cooling in lean women. Journal of Physiology 1988; 399: 74P.

48 Gallen IW, Macdonald IA. The effects of underfeeding for seven days on the thermogenic and the physiological responses to glucose and insulin infusion (hyperinsulinaemic euglycaemic clamp). British Journal of Nutrition 1990; 64: $427-37$.

49 Fellows IW, Macdonald IA, Bennett T, Allison SP. The effect of undernutrition on thermoregulation in the elderly. Clinical Science 1985; 69: 919-21.

50 Dulloo AG, Jacquet G, Girardier L. Autoregulation of body composition during weight recovery in humans: the Minnesota experiment revisited. International Journal of Obesity 1996; 20: 393-405.

51 Weinsier RL, Nagy TR, Hunter GR, Darnell BE, Hensrud DD, Weiss HL. Do adaptive changes in metabolic rate favor weight regain in weight-reduced individuals? An examination of the set-point theory. American Journal of Clinical Nutrition 2000; 72: 1088-94.

52 Ashworth A. An investigation of very low calorie intakes reported in Jamaica. British Journal of Nutrition 1968; 22: $341-55$.

53 Velthuis-te Wierik EJ, Hoogzaad LV, van den Berg $\mathrm{H}$, Schaafsma G. Effects of moderate energy restriction on physical performance and substrate utilization in nonobese men. International Journal of Sports Medicine 1994; 15: $478-84$.

54 Gorsky RD, Calloway DH. Activity pattern changes with decrease in food intake. Human Biology 1983; 55: 577-96.

55 Gopalan C. Heights of population - an index of their nutrition and socio-economic development. Bulletin of the Nutrition Foundation of India 1987; 8: 1-5.

56 Ferro-Luzzi A, Petracchi C, Kuriyan R, Kurpad AV. Basal metabolism of weight stable chronically undernourished men and women: lack of metabolic adaptation and ethnic differences. American Journal of Clinical Nutrition 1997; 66: $1086-93$.

57 McNeill G, Rivers JPW, Payne PR, deBritto JJ, Abel R. Basal metabolic rate of Indian men: no evidence of adaptation to a low plane of nutrition. Human Nutrition Clinical Nutrition 1987; 41C: 473-84.

58 Soares MJ, Piers LS, Shetty PS, Robinson S, Jackson AA, Waterlow JC. Basal metabolic rate, body composition and whole body protein turnover in Indian men with different nutritional status. Clinical Science 1991; 81: 419-25.

59 Soares MJ, Piers LS, Shetty PS, Jackson AA, Waterlow JC. Whole body protein turnover in chronically undernourished individuals. Clinical Science 1994; 58: 441-6.

60 Barac-Nieto M, Spurr GB, Lotero H, Maksud MG. Body composition in chronic undernutrition. American Journal of Clinical Nutrition 1978; 31: 23-40.

$61 \mathrm{FAO} / \mathrm{WHO} / \mathrm{UNU}$. Energy and protein requirements. Report of a Joint FAO/WHO/UNU Expert Consultation. Technical Report Series, No.724. Geneva: World Health Organization, 1985.

62 Srikantia SG. Nutritional adaptation in man. Proceedings of the Nutrition Society of India 1985; 31: 1-16.

63 Kurpad AV, Kulkarni RN, Sheela ML, Shetty PS. Thermogenic responses to graded doses of noradrenaline in undernourished Indian male subjects. British Journal of Nutrition 1989; 61: 201-8

64 Kurpad AV, Kulkarni RN, Shetty PS. Reduced thermoregulatory thermogenesis in undernutrition. European Journal of Clinical Nutrition 1989; 43: 27-33. 
65 Bianca PD, Jequier E, Schutz Y. Lack of metabolic and behavioral adaptations in rural Gambian men with low body mass index. American Journal of Clinical Nutrition 1994; 60: 37-42

66 Weinsier RL, Schutz Y, Bracco D. Re-examination of the relationship of resting metabolic rate to fat free mass and to the metabolicly active components of fat-free mass in humans. American Journal of Clinical Nutrition 1992; 55 790-4.

67 Soares MJ, Shetty PS. Basal metabolic rates and metabolic economy in chronic undernutrition. European Journal of Clinical Nutrition 1991; 45: 363-73.

68 Lawrence M, Thongprasert K, Durnin JVGA. Betweengroup differences in basal metabolic rates: an analysis of data collected in Scotland, The Gambia and Thailand. European Journal of Clinical Nutrition 1988; 42: 877-91.

69 Shetty PS. Adaptive changes in basal metabolic rate and lean body mass in chronic undernutrition. Human Nutrition Clinical Nutrition 1984; 38C: 443-52.

70 Schofield WN. Predicting basal metabolic rate: new standards and review of previous work. Human Nutrition Clinical Nutrition 1985; 1: 5-41.

71 Henry CJ, Rees DG. New predictive equations for the estimation of basal metabolic rate in tropical peoples. European Journal of Clinical Nutrition 1991; 45: 177-85.

72 Heini AF, Minghelli G, Diaz E, Prentice AM, Schutz Y. Free living energy expenditure assessed by two methods in rural Gambia. European Journal of Clinical Nutrition 1996; 50: 284-9.

73 Shetty PS, Henry CJK, Black AE, Prentice AM. Energy requirements of adults: an update on basal metabolic rates (BMRs) and physical activity levels (PALs). European Journal of Clinical Nutrition 1996; 50(Suppl. 1): S11-S23.

74 Shetty PS, Kurpad AV. Role of the sympathetic nervous system in adaptation to seasonal energy deficiency. European Journal of Clinical Nutrition 1990; 44(Suppl. 1): $47-54$.

75 Vaz M, Kurpad AV, Thangam S, Shetty PS. Thermal, cardiovascular and thermogenic responses to mild cold exposure in chronically energy deficient subjects. Indian Journal of Medical Research 1997; 105: 180-6.

76 Cannon P, Keatinge WR. The metabolic rate and heat loss of fat and thin men in heat balance in cold and warm water. Journal of Physiology 1960; 154: 329-44.

77 Strong LH, Gee GK, Goldman RF. Metabolic and vasomotor insulative responses occurring on immersion in cold water. Journal of Applied Physiology 1985; 58: 964-77.

78 Piers LS, Soares MJ, Shetty PS. Thermic effect of a meal. Role in chronic undernutrition. British Journal of Nutrition 1992; 67: $177-85$.

79 Schoeller DA, Van Santen E. Measurements of energy expenditure in humans by doubly labelled water method. Journal of Applied Physiology 1982; 53: 955-9.

80 IDECG. The doubly labelled water method for measuring energy expenditure: Technical recommendations for use in humans. A consensus report by the IDECG Working Group. Vienna: International Dietary Energy Consultative Group, 1990; 90-113.

81 Borgonha S, Shetty PS, Kurpad AV. Total energy expenditure and physical activity in chronically undernourished Indian males measured by the doubly labelled water method. Indian Journal of Medical Research 2000; 111: $24-32$.

82 Durnin JVGA, Drummond S, Satyanarayana K. A collaborative study on seasonality and marginal nutrition: The Glasgow Hyderabad (S. India) study. European Journal of Clinical Nutrition 1990; 44(Suppl. 1): 19-29.

83 James WPT, Schofield EC. Human Energy Requirements. A Manual for Planners and Nutritionists. Oxford: Food and
Agriculture Organization and Oxford University Press, 1990.

84 Garrow JS, Webster JD. Thermogenesis to small stimuli. In: van Es AJH, ed. Human Energy Metabolism. Wageningen: Euro-Nut, 1985; 215-24.

85 Waterlow JC. Metabolic adaptation to low intakes of energy and protein. Annual Review of Nutrition 1986; 6: 495-526.

86 Levine JA, Eberhardt NL, Jensen MD. Role of nonexercise activity thermogenesis in resistance to fat gain in humans. Science 1999; 283: 212-4.

87 Haggarty P, Valencia ME, McNeill G, Gonzales NL, Moya SY, Pinelli A, Quihui L, Saucedo MS, Esparza J, Ashton J, Milne E, James WPT. Energy expenditure during heavy work and its interaction with body weight. British Journal of Nutrition 1997; 77: 359-73.

88 Waterlow JC. The nature and significance of nutritional adaptation. European Journal of Clinical Nutrition 1999; 53(Suppl. 1): S2-S5.

89 Torun B, Flores R, Viteri F, Immink M, Diaz E. Energy Supplementation and Work Performance: Summary of INCAP Studies. Seoul: Proceedings of the XIV International Congress on Nutrition, 1989; 306-9.

90 Desai ID, Wadell C, Dutra S, Dutra de Oliveira S, Duarte E, Robazzi ML, Romero CLS, Desai MI, Vichi FL, Bradfield RB, Dutra de Oliveira JE. Marginal malnutrition and reduced physical work capacity of migrant adolescent boys in southern Brazil. American Journal of Clinical Nutrition 1984; 40: 135-45.

91 Spurr GB, Barac-Nieto M, Maksud MG. Productivity and maximal oxygen consumption in sugar cane cutters. American Journal of Clinical Nutrition 1977; 30: 316-21.

92 Spurr GB. The effects of chronic energy deficiency on stature, work capacity and productivity. In: Scrimshaw $\mathrm{N}$, Schurch B, eds. Effects of Chronic Energy Deficiency on Stature, Work Capacity and Productivity. Lausanne, Switzerland: International Dietary Energy Consultancy Group, 1987; 95-134.

93 Satyanarayana K, Naidu AN, Narasinga Rao BS. Body size and work output. American Journal of Clinical Nutrition 1977; 30: 322-5

94 Satyanarayana K, Naidu AN, Narasinga Rao BS. Nutrition, physical work capacity and work output. Indian Journal of Medical Research 1978; 68(Suppl.): 88-93.

95 Immink MDC, Viteri FE, Helms RW. Energy intakes and the life cycle and human capital formation in Guatemalan sugar cane cutters. Economic Development and Cultural Change 1982; 30: 351-72.

96 Haddad L, Bouis H. The impact of nutritional status on agricultural productivity: wage evidence from the Philippines. Oxford Bulletin of Economics and Statistics 1991; 53: 45-68.

97 Kennedy E, Garcia M. Body mass index and economic productivity. European Journal of Clinical Nutrition 1994; 48(Suppl. 3): S45-S55.

98 Malina RM. Motor development and performance of children and youth in undernourished populations. In: Katch FI, ed. Sport, Health and Nutrition Campaign. Illinois: Human Kinetics, 1985; 213-26.

99 Vaz M, Thangam S, Prabhu A, Shetty PS. Maximal voluntary contraction as functional indicator of adult chronic undernutrition. British Journal of Nutrition 1996; 76: 9-15.

100 Padmavathi R, Kurpad AV, Vaz M. Skeletal muscle endurance is reduced in chronically energy deficient adults. Indian Journal of Medical Research 2000; 111: 28-34.

101 Viteri FE. Considerations on the effect of nutrition on the body composition and physical working capacity of young Guatemalan adults. In: Scrimshaw NS, Altschul AM, eds. Amino Acid Fortification of protein Foods. Cambridge, MA: MIT Press, 1971; 350-75. 
102 Kulkarni RN, Shetty PS. Increased net mechanical efficiency during stepping in chronically energy deficient human subjects. Annals of Human Biology 1992; 19: 421-5.

103 Barac-Nieto M, Spurr GB, Dahners HW, Maksud MG. Aerobic work capacity and endurance during nutritional repletion of severely undernourished men. American Journal of Clinical Nutrition 1980; 33: 2268-75.

104 Kulkarni RN, Kurpad AV, Shetty PS. Reduced postexercise recovery oxygen consumption: an adaptive response in chronic energy deficiency? Metabolism 1993; 42: 544-7.

105 Spurr GB, Barac-Nieto M, Reina JC, Ramirez R. Marginal malnutrition in school aged Colombian boys: efficiency of treadmill walking in submaximal exercise. American Journal of Clinical Nutrition 1984; 39: 452-9.

106 Spurr GB, Dufour DL, Reina JC. Increased muscular efficiency during lactation in Colombian women. European Journal of Clinical Nutrition 1998; 52: 17-21.

107 Russell DM, Walker PM, Leiter LA, Sima A, Tanner WK, Mickle DAG, Whitwell J, Marliss EB, Jeejeebhoy KN. Metabolic and structural changes in skeletal muscle during hypocaloric dieting. American Journal of Clinical Nutrition 1984; 39: 503-13.

108 Henriksson J. The possible role of skeletal muscle in the adaptation to periods of energy deficiency. European Journal of Clinical Nutrition 1990; 44(Suppl. 1): 55-64.

109 Geissler CA, Hamool AMA. Racial difference in energy cost of different activities. Annals of Nutrition and Metabolism 1985; 29: 40-7.

110 Latham MC. Nutrition and work performance, energy intakes and human wellbeing in Africa. Proceedings of the XIV International Congress on Nutrition 1989: 314-7 Seoul.

111 Maloiy GMO, Hegland NC, Prager LM, Cavagna G, Taylor CR. Energetic costs of carrying loads: have African women discovered an economic way? Nature 1986; 319: 668-9.

112 James WPT, Francois PJ. The choice of cut-off points for distinguishing normal weights from underweight or 'chronic energy deficiency' in adults. European Journal of Clinical Nutrition 1994; $\mathbf{4 8}$ (Suppl. 3): S179-84.

113 Garcia M, Kennedy E. Assessing the linkages between low body mass index and morbidity in adults: evidence from four developing countries. European Journal of Clinical Nutrition 1994; 48 (Suppl. 3): S90-7.

114 Chandra RK. Nutrition, immunity and infection: present knowledge and future direction. Lancet 1983; I: 688-91.

115 Strickland SS, Ulijaszek SJ. Body mass index and illness in rural Sarawak. European Journal of Clinical Nutrition 1994; 48(Suppl. 3): S98-S109.

116 De Vasconcellos MTL. Body Mass Index: its relationship with food consumption and socio-economic variables in Brazil. European Journal of Clinical Nutrition 1994; 48(Suppl. 3): S115-23.

117 Campbell P, Ulijaszek SJ. Relationships between anthropometry and retrospective morbidity in poor men in Calcutta, India. European Journal of Clinical Nutrition 1994; 48: 507-12.

118 Dulloo AG, Jacquet J, Girardier L. Poststarvation hyperphagia and body fat overshooting in humans: a role for feedback signals from lean and fat tissues. American Journal of Clinical Nutrition 1997; 65: 717-23.

119 Barac-Nieto M, Spurr GB, Lotero H, Maksud MG, Dahners HW. Body composition during nutritional repletion of severely undernourished men. American Journal of Clinical Nutrition 1979; 32: 981-91.

120 Durnin JVGA, Womersley J. Body Fat assessed by total body density and its estimation from skinfold thickness: measurements on 481 men and women aged from 16 to 72 years. British Journal of Nutrition 1974; 32: 77-97.

121 Kuriyan R, Petracchi C, Ferro-Luzzi A, Shetty PS, Kurpad AV. Validation of expedient methods for measuring body composition in Indian adults. Indian Journal of Medical Research 1998; 107: 37-45.

122 Grande F. Man under caloric deficiency. Handbook of Physiology. Adaptation to the Environment. Washington, DC: American Physiological Society, 1964; 911-37.

123 Koong LJ, Ferrel CL. Effects of short term nutritional manipulation on organ size and fasting heat production. European Journal of Clinical Nutrition 1990; 44: 73-7.

124 Vaz M, Kulkarni RN, Soares MJ, Kurpad AV, Shetty PS. Thermogenic responses to noradrenaline are unaltered following energy supplementation in chronically energy deficient subjects. European Journal of Clinical Investigation 1991; 21: 27-32.

125 Ramaiya KL, Kodali VRR, Alberti KGMM. Epidemiology of diabetes in Asians of the Indian Subcontinent. Diabetes/Metabolism Reviews 1990; 6: 125-46.

126 Gupta R, Gupta VP. Meta-analysis of coronary heart disease prevalence in India. International Heart Journal 1996; 48 : $241-5$.

127 Gopalan C. Micronutrient deficiencies - Public health implications. Nutrition Foundation of India Bulletin 1994; 15: $1-6$.

128 Gopalan C. Diet related non-communicable disease in South and South-East Asia. In: Shetty PS, McPherson K, eds. Diet, Nutrition and Chronic Disease. Lessons from Contrasting Worlds. London: John Wiley and Sons, 1997; $10-23$.

129 McKeigue PM, Pierpoint T, Ferrie JE, Marmot MG. Relationship of glucose intolerance and hyperinsulinaemia to body fat pattern in South Asians and Europeans. Diabetologia 1992; 35: 785-91.

130 Ramachandran A, Snehalatha C, Dharmaraj D, Viswanathan M. Prevalence of glucose intolerance in Asian Indians. Urban-rural difference and significance of upper body obesity. Diabetes Care 1992; 15: 1348-55.

131 McKeigue PM, Shah B, Marmot MG. Relation of central obesity and insulin resistance with high diabetes prevalence and cardiovascular risk in South Asians. Lancet 1991; 337: $971-3$.

132 Fall CHD, Yajnik CS, Rao S, Coyaji KJ. The effects of maternal body composition before pregnancy on fetal growth: The Pune Maternal Nutrition Study. In: O'Brien PMS, Wheeler T, Barker DJP, eds. Fetal Programming Influences on Development and Disease in Later Life. London: RCOG, 1999; 231-45.

133 Yudkin JS, Stehouwer CDA, Emeis JJ, Coppack SW. Creactive protein in healthy subjects: Associations with obesity, insulin resistance, and endothelial dysfunction. Arteriosclerosis, Thrombosis, and Vascular Biology 1999; 19: $972-8$.

134 Steppan CM, Bailey ST, Bhat S, Brown EJ, Banerjee RR, Wright CM, Patel HR, Ahima RS, Lazar MA. The hormone resistin links obesity to diabetes. Nature 2001; 409: 307-12.

135 Fukagawa NK, Bandini LG, Young VR. Effect of age on body composition and resting metabolic rate. American Journal of Physiology 1990; 259: E233-8.

136 Poehlman ET, Goran MI, Gardner AW, Ades PA, Arciero PJ, Katzman-Rooks SM, Montgomery SM, Toth MJ, Sutherland PT. Determinants of decline in resting metabolic rate in aging females. American Journal of Physiology 1993; 264: E450-5.

137 Hunter GR, Weinsier RL, Gower BA, Wetzstein C. Agerelated decrease in resting energy expenditure in sedentary white women: effects of regional differences in lean and fat mass. American Journal of Clinical Nutrition 2001; 73 : $333-7$.

138 Elia M, Ritz P, Stubbs RJ. Total energy expenditure in the elderly. European Journal of Clinical Nutrition 2000; 54(Suppl. 3): S92-103.

139 Withers RT, Smith DA, Tucker RC, Brinkman M, Clark DG. 
Energy metabolism in sedentary and active 49- to 70-year old women. Journal of Applied Physiology 1998; 84: $1333-40$.

140 Schwartz RS, Jaeger LF, Vieth RC. The thermic effect of feeding in older men: the importance of the sympathetic nervous system. Metabolism 1990; 39: 733-7.

141 Kerckhoffs DAJM, Blaak EE, Van Baak MA, Saris WHM. Effect of aging on $\beta$-adrenergically mediated thermogenesis in men. American Journal of Physiology 1998; 274: E1075-9.

142 Fuller NJ, Sawyer MB, Coward WA, Paxton P, Elia M. Components of total energy expenditure in free-living adult men (over 75 years of age): measurement, predictability and relationship to quality-of-life indices. British Journal of Nutrition 1996; 75: 161-73.

143 Cohn SH, Varstky D, Yasamura S, Sawitsky A, Zanzi I, Vaswani A, Ellis KJ. Compartmental body composition based on total body nitrogen, potassium and calcium. American Journal of Physiology 1980; 239: E524-30.

144 Roberts SB, Dallal GE. Effects of age on energy balance. American Journal of Clinical Nutrition 1998; 68(Suppl.): S975-9

145 Roberts SB, Fuss P, Dallal GE, Atkinson A, Evans WJ, Joseph L, Fiatarone MA, Greenberg AS, Young VR. Effects of age on energy expenditure and substrate oxidation during experimental overfeeding in healthy men. Journals of Gerontology. Series A, Biological Sciences and Medical Sciences 1996; 51: B148-57.

146 Moriguti JC, Das SK, Saltzman E, Corrales A, McCrory MA, Greenberg AS, Roberts SB. Effects of a 6-week hypocaloric diet on changes in body composition, hunger, and subsequent weight regain in healthy young and older adults. Journals of Gerontology. Series A, Biological Sciences and Medical Sciences 2000; 55: B580-7.

147 Roberts SB. Effects of aging on energy requirements and the control of food intake in men. Journals of Gerontology. Series A, Biological Sciences and Medical Sciences 1995; 50(Spec No): 101-6

148 Rising R, Tataranni PA, Snitker S, Ravussin E. Decreased ratio of fat to carbohydrate oxidation with increasing age in Pima Indians. Journal of the American College of Nutrition 1996; 15: 309-12.

149 Toth MJ, Poehlman ET. Energetic adaptation to chronic disease in the elderly. Nutrition Review 2000; 58: 61-6.

150 Poehlman ET, Dvorak RJ. Energy expenditure, energy intake, and weight loss in Alzheimer disease. American Journal of Clinical Nutrition 2000; 71: 650S-5S.

151 Pieterese S, Manandhar M, Ismail S. The nutritional status of older Rwandan refugees. Public Health Nutrition 1998; 1: 259-64.

$152 \mathrm{Ng} \mathrm{AV}$, Callister R, Johnson DG, Seals DR. Age and gender influence muscle sympathetic nerve activity at rest in healthy humans. Hypertension 1993; 21: 498-503.

153 Esler MD, Turner AG, Kaye DM, Thompson JM, Kingwell BA, Morris M, Lambert GW, Jennings GL, Cox H, Seals DR. Aging effects on human sympathetic neuronal function. American Journal of Physiology 1995; 268: R278-85.

154 McGuire J, Popkin BM. Beating the zero sum game: women and nutrition in the Third World. Food and Nutrition Bulletin 1989; 11: 38-63.

155 Merchant K, Martorell R. Frequent reproductive cycling: does it lead to nutritional depletion of mothers? Progress in Food \& Nutrition Science 1988; 12: 339-69.

156 Prentice AM, Whitehead RG. The energetics of human reproduction. Symposium of the Zoological Society of London 1987; 57: 275-304.

157 Frisch RE, McCarthur JW. Menstrual cycles: Fatness as a determinant of minimum weight for height necessary for their maintenance or onset. Science 1974; 185: 949-51.

158 Frisch RE. Nutrition, fatness and fertility: The effect of food intake on reproductive ability. In: Mosley WH, ed. Nutrition and Human Reproduction. New York: Plenum Press, 1978; 91-122.

159 Lawrence M, Lawrence F, Lamb WH, Whitehead RG. Maintenance energy cost of pregnancy in rural Gambian women and influence of dietary status. Lancet 1984; 2 363-5.

160 Poppitt SD, Prentice AM, Jequier E, Schutz Y, Whitehead RG. Evidence of energy-sparing in Gambian women during pregnancy: a longitudinal study using whole-body calorimetry. American Journal of Clinical Nutrition 1993; 57 353-64.

161 Hytten FE. Nutrition. In: Hytten FE, Chamberlain G, eds. Clinical Physiology in Obstetrics. Oxford: Blackwell Scientific Publications, 1991; 150-72.

162 Lawrence M, Lawrence F, Coward WA, Cole TJ, Whitehead R. Energy requirements of pregnancy in the Gambia. Lancet 1987; 2: 1072-6

163 Durnin JVGA, McKillop FM, Grant S, Fitzgerald G. Energy requirements of pregnancy in Scotland. Lancet 1987; 2 897-900.

164 van Raaij JMA, Vermaat-Miedema SH, Schonk CM, Peek MEM, Hautvast JGAJ. Energy requirements of pregnancy in the Netherlands. Lancet 1987; 2: 953-5.

165 Thongprasert K, Tanphaichitre V, Valyasevi A, Kittigool J, Durnin JVGA. Energy requirements of pregnancy in the Philippines. Lancet 1987; 2: 1110-2.

166 Tuazon MAG, van Raaij JMA, Hautvast JGAJ, Barba CVC. Energy requirements of pregnancy in the Philippines. Lancet 1987; 2: 1129-31.

167 Forsum E, Sadurkis A, Wager J. Resting metabolic rate and body composition of healthy Swedish women during pregnancy. American Journal of Clinical Nutrition 1988; 47: $942-7$.

168 Goldberg GR, Prentice AM, Coward WA, Davies HL, Murgatroyd PR, Wensing C, Black AE, Harding M, Sawyer M. Longitudinal assessment of energy expenditure in pregnancy by the doubly labelled water method. American Journal of Clinical Nutrition 1993; 57: 494-505.

169 Spaaij CJK. Critical reassessment of the energy needs during pregnancy. In: The efficiency of energy metabolism during pregnancy and lactation in well nourished Dutch women. PhD thesis. Wageningen: Wageningen Agricultural University, 1993.

170 King JC, Butte NF, Bronstein MN, Kopp LE, Lindquist SA. Energy metabolism during pregnancy: influence of maternal energy status. American Journal of Clinical Nutrition 1994; 59(Suppl.): S439-45.

171 Piers LS, Diggavi SN, Thangam S, van Raaij JMA, Shetty PS, Hautvast JGAJ. Changes in energy expenditure, anthropometry, and energy intake during the course of pregnancy and lactation in well-nourished Indian women. American Journal of Clinical Nutrition 1995; 61: 501-13.

172 Hoolihan LEP, van Loan MD, Wong WW, King JC. Longitudinal assessment of energy balance in wellnourished pregnant women. American Journal of Clinical Nutrition 1999; 69: 697-704.

173 Lawrence M, Whitehead RG. Physical activity and total energy expenditure in childbearing Gambian women. European Journal of Clinical Nutrition 1988; 42: 145-60.

174 Dufour DL, Reina JC, Spurr GB. Energy intake and expenditure of free-living, pregnant Colombian women in an urban setting. American Journal of Clinical Nutrition 1999; 70: 269-76.

175 Kramer MS. Determinants of low birth weight: methodological assessment and meta-analysis. Bulletin of the World Health Organization 1987; 65: 663-737.

176 Giay T, Khoi HH. Use of body mass index in the assessment of adult nutritional status in Vietnam. European Journal of Clinical Nutrition 1994; 48(Suppl. 3): S124-30. 
177 Allen LH, Lung'aho MS, Shaheen M, Harrison GG, Neumann C, Kirksey A. Maternal body mass index and pregnancy outcome in the Nutrition Collaborative Research Support Program. European Journal of Clinical Nutrition 1994; 48(Suppl. 3): S68-77.

178 Kusin JA, Kardjati S, Renqvist UH. Maternal body mass index: the functional significance during reproduction. European Journal of Clinical Nutrition 1994; 48(Suppl. 3): S56-S67.

179 National Institute of Nutrition, Indian Council of Medical Research (NIN/ICMR), 1983. Annual Report for the period January to December, New Delhi, 1983.

180 Naidu AN, Rao NP. Body mass index: a measure of the nutritional status in Indian populations. European Journal of Clinical Nutrition 1994; 48(Suppl. 3): S131-40.

181 Abrams BF, Laros RK Jr. Prepregnancy weight, weight gain and birth weight. American Journal of Obstetrics and Gynecology 1986; 154: 503-9.

182 Kusin JA, Kardjati S, Renqvist UH, Goei K. Reproduction and maternal nutrition in Madura, Indonesia. Tropical and Geographical Medicine 1992; 44: 248-55.

183 Prentice AM, Spaaij CJK, Goldberg GR, Poppitt SD, van Raaij JMA, Totton M, Swann D, Black AE. Energy requirements of pregnant and lactating women. European Journal of Clinical Nutrition 1996; 50(Suppl. 1): S82-S111.

184 Prentice AM, Goldberg GR, Prentice A. Body mass index and lactation performance. European Journal of Clinical Nutrition 1994; 48: S78-89.

185 Barbosa L, Butte NF, Villalpando S, Wong WW, Smith EO. Maternal energy balance and lactation performance of mesoamerindians as a function of body mass index. American Journal of Clinical Nutrition 1997; 66: 575-83.

186 Madhavapeddi R, Narasinga Rao BS. Energy balance in lactating undernourished Indian women. European Journal of Clinical Nutrition 1992; 46: 349-54.

187 Gopalan C. Studies on lactation in poor Indian communities. Journal of Tropical Pediatrics 1958; 4: 87-97.

188 Belavady B. Quantity and composition of breast milk in malnourished mothers. In: Hambreus L, Sjohn L, eds. Symposia of the Swedish Nutrition Foundation. Sweden: Almqvist and Wiksell, 1979: Vol 4.

189 Perez-Escamilla R, Cohen RJ, Brown KH, Rivera LL, Canahuati J, Dewey KG. Maternal anthropometric status and lactation performance in a low-income Honduran population: evidence for the role of infants. American Journal of Clinical Nutrition 1995; 61: 528-34.

190 Prema K, Madhavapeddi R, Ramalakshmi BA. Changes in anthropometric indices of nutritional status in lactating women. Nutrition Reports International 1981; 24: 893-900.

191 Huffman SL, Chowdhury AKMA, Chakraborty J, Simpson N. Breastfeeding patterns in rural Bangladesh. American Journal of Clinical Nutrition 1980; 33: 144-53.

192 Tuazon MAG, Barba CV, van Raaij JMA, Hautvast JGAJ. Energy intake, energy expenditure and body composition of poor rural Philippine women throughout the first 6 months of lactation. American Journal of Clinical Nutrition 1992; 56: 874-80.

193 Sadurkis A, Kabir N, Wager J, Forsum E. Energy metabolism, body composition and milk production in healthy Swedish during lactation. American Journal of Clinical Nutrition 1988; 48 : 44-9.

194 van Raaij JM, Schonk CM, Vermaat-Miedema SH, Peek ME, Hautvast JGAG. Energy cost of lactation, and energy balances of well-nourished Dutch lactating women: reappraisal of the extra energy requirements of lactation. American Journal of Clinical Nutrition 1991; 53: 612-9.

195 Goldberg GR, Prentice AM, Coward WA, Davies HL, Murgatroyd PR, Sawyer MB, Ashford J, Black AE. Longitudinal assessment of the components of energy balance in well-nourished lactating women. American Journal of Clinical Nutrition 1991; 54: 788-98.

196 Delpeuch F, Cornu A, Massamba J-P, Traissac P, Maire B. Is body mass index sensitively related to socio-economic status and to economic adjustment? A case study from the Congo. European Journal of Clinical Nutrition 1994; 48(Suppl. 3): S141-7.

197 Rahman M, Roy SK, Ali M, Alam AN, Akbar MS. Maternal nutritional status as a determinant of child health. Journal of Tropical Pediatrics 1993; 39: 86-8.

198 Allen LH. Nutritional influences on linear growth: a general review. European Journal of Clinical Nutrition 1994; 48(Suppl. 1): S75-S89.

199 Grantham-McGregor S. Effects of health and nutrition on cognitive and behavioral development in children in the first three years of life. Part 1: Low birth weight, breastfeeding and protein-energy malnutrition. Food and Nutrition Bulletin 1999; 20: 53-75.

200 Martorell R. The nature of child malnutrition and its longterm implications. Food and Nutrition Bulletin 1999; 20: 288-92.

201 WHO. Report of a WHO Expert Committee. Physical Status: the Use and Interpretation of Anthropometry. WHO Technical Report Series No. 854. Geneva: World Health Organization, 1995.

202 Laitinen J, Power C, Järvelin M. Family social class, maternal body mass index, childhood body mass index, and age at menarche as predictors of adult obesity. American Journal of Clinical Nutrition 2001; 74: 287-94.

203 Gunnell DJ, Frankel SJ, Nanchahal K, Peters TJ, Smith GD. Childhood obesity and adult cardiovascular mortality: a 57y follow-up study based on the Boyd Orr cohort. American Journal of Clinical Nutrition 1998; 67: 1111-8.

204 Chaturvedi S, Kapil U, Gnanasekaran N, Sachdev HP, Pandey RM, Bhanti T. Nutrient intake amongst adolescent girls belonging to poor socioeconomic group of rural area of Rajasthan. Indian Journal of Pediatrics 1996; 33 : 197-201.

205 Wang Y, Ge K, Popkin BM. Tracking of body mass index from childhood to adolescence: a 6-y follow-up study in China. American Journal of Clinical Nutrition 2000; 72 : $1018-24$.

206 Martorell R. Comment on anthropometry in studies of malnutrition and behavior. In: Brozek J, Schurch B, eds. Malnutrition and Behavior: Critical Assessment of Key Issues. Lausanne: Nestle Foundation, 1984; 71-6.

207 Garrow JS, Smith R, Ward EE. Electrolyte Metabolism in Severe Infantile Malnutrition. Oxford: Pergamon Press, 1968.

208 Alleyne GAO, Hay RW, Picou DI, Stanfield JP, Whitehead RG. Body fluids. In: Arnold E, ed. Protein Energy Malnutrition. London: 1977; 1-244.

209 Mora JO. Nutritional assessment by anthropometry: prevalence studies. In: Brozek J, Schurch B, eds. Malnutrition and Behavior: Critical Assessment of Key Issues. Lausanne: Nestle Foundation, 1984; 98-106.

210 Varga F. The respective effects of starvation and changed body composition on energy metabolism in malnourished infants. Pediatrics 1959; 23: 1085-90.

211 Parra A, Garza C, Garza Y, Saravia JL, Hazlewood CF, Nichols BL. Changes in growth hormone, insulin, and thyroxine values, and in energy metabolism of marasmic infants. Journal of Pediatrics 1973; 82: 133-42.

212 Brooke OG, Cocks T, March Y. Resting metabolic rate in malnourished babies in relation to total body potassium. Acta Paediatrica Scandinavica 1974; 63: 817-25.

213 Montgomery RD. Changes in the basal metabolic rate of the malnourished infant and their relation to body composition. Journal of Clinical Investigation 1962; 41: 1653-63.

214 Rao JKS, Khan L. Basal energy metabolism in protein 
calorie malnutrition and vitamin A deficiency. American Journal of Clinical Nutrition 1974; 27: 892-6.

215 Vasquez-Velasquez L. Energy expenditure and physical activity of malnourished Gambian children. Proceedings of the Nutrition Society 1988; 47: 233-9.

216 Torun B, Davies PSW, Livingstone MBE, Paolisso M, Sackett R, Spurr GB. Energy requirements and dietary energy recommendations for children and adolescents 1 to 18 years old. European Journal of Clinical Nutrition 1996; 50(Suppl. 1): S37-81.

217 Butte NF, Wong WW, Hopkinson JM, Heinz CJ, Mehta NR, Smith EO'B. Energy requirements derived from total energy expenditure and energy deposition during the first 2 years of life. American Journal of Clinical Nutrition 2000; 72 : 1558-69.

218 Stunkard AJ, Berkowitz RI, Stallings VA, Schoeller DA Energy intake, not energy output, is a determinant of body size in infants. American Journal of Clinical Nutrition 1999; 69: $524-30$

219 Spurr GB, Reina JC. Energy expenditure/basal metabolic ratios in normal and marginally undernourished Colombian children 6-16 years of age. European Journal of Clinical Nutrition 1989; 43: 515-27.

220 Rutishauser IHE, Whitehead RG. Energy intake and expenditure in 1-3 year old Ugandan children living in a rural environment. British Journal of Nutrition 1972; 28 : $145-52$

221 Hurwitz I. Psychometric methods. In: Brozek J, Schurch B, eds. Malnutrition and Behavior: Critical Assessment of Key Issues. Lausanne: Nestle Foundation, 1984; 164-76.

222 Brozek J. Psychometric methods: an addendum. In: Brozek J, Schurch B, eds. Malnutrition and Behavior: Critical Assessment of Key Issues. Lausanne: Nestle Foundation, 1984; 177-85.

223 Brozek J, Schurch B. Malnutrition and Behavior: Critical Assessment of Key Issues. Lausanne: Nestle Foundation, 1984.

224 Gardner JM, Grantham-McGregor SM, Himes J, Chang S. Behaviour and development of stunted and nonstunted Jamaican children. Journal of Child Psychology and Psychiatry, and Allied Disciplines 1999; 40: 819-27.
225 Gorman KS. Malnutrition and cognitive development: evidence from experimental/quasi-experimental studies among the mild-to-moderately malnourished. Journal of Nutrition 1995; 125(Suppl. 8): S2239-44.

226 Pollitt E, Schurch B. eds Developmental pathways of the malnourished child: results of a supplementation trial in Indonesia. European Journal of Clinical Nutrition 2000; 54(Suppl. 2): S1-119.

227 Walka H, Triana N, Jahari AB, Husaini MA, Pollitt E. Effects of an energy and micronutrient supplement on play behavior in undernourished children in Indonesia European Journal of Clinical Nutrition 2000; 54(Suppl. 2): S91-106

228 Grantham-McGregor S, Powell CA, Walker SP, Himes JH. Nutritional supplementation, psychosocial stimulation, and mental development of stunted children: the Jamaican study. Lancet 1991; 338: 1-5.

229 Pollitt E, Gorman KS, Engle PL, Rivera JA, Martorell R. Nutrition in early life and the fulfillment of intellectual potential. Journal of Nutrition 1995; 125(Suppl. 4): S1111-8.

230 Ferro-Luzzi A, Scaccini C, Taffese S, Aberra B, Demeke T. Seasonal energy deficiency in Ethiopian rural women. European Journal of Clinical Nutrition 1990; 44: 7-18.

231 Valencia ME, Moya SY, McNeill G, Haggarty P. Basal metabolic rate and body fatness of adult men in northern Mexico. European Journal of Clinical Nutrition 1994; 48 205-11.

232 Schultink JW, Klaver W, Van Wijk H, Van Raaij JMA, Hautvast JGAJ. Body weight changes and basal metabolic rates of rural Beninese women during seasons with different energy intakes. European Journal of Clinical Nutrition 1990; 44: 31-40.

233 Schultink JW, Van Raaij JMA, Hautvast JGAJ. Seasonal weight loss and metabolic adaptation in rural Beninese women: the relation with body mass index. British Journal of Nutrition 1993; 70: 689-700.

234 Spurr GB, Dufour DL, Reina JC, Hoffman RG, Waslien C, Staten LK. Variation of the basal metabolic rate and dietary energy intake of Colombian women during $1 \mathrm{y}$. American Journal of Clinical Nutrition 1994; 59: 20-7. 